\title{
How many of Cassini anagrams should there be? Molecular systematics and phylogenetic relationships in the Filago group (Asteraceae, Gnaphalieae), with special focus on the genus Filago
}

\author{
Mercè Galbany-Casals, ${ }^{1,3}$ Santiago Andrés-Sánchez, ${ }^{2,3}$ Núria Garcia-Jacas, ${ }^{1}$ Alfonso Susanna, ${ }^{1}$ \\ Enrique Rico $^{2}$ \& M. Montserrat Martínez-Ortega ${ }^{2}$ \\ 1 Institut Botànic de Barcelona (CSIC-ICUB), Pg. del Migdia s.n., 08038 Barcelona, Spain \\ 2 Departamento de Botánica, Facultad de Biología, Universidad de Salamanca, 37007 Salamanca, Spain \\ 3 These authors contributed equally to this publication. \\ Author for correspondence: Mercè Galbany-Casals, pallenis@yahoo.com
}

\begin{abstract}
The Filago group (Asteraceae, Gnaphalieae) comprises eleven genera, mainly distributed in Eurasia, northern Africa and northern America: Ancistrocarphus, Bombycilaena, Chamaepus, Cymbolaena, Evacidium, Evax, Filago, Logfia, Micropus, Psilocarphus and Stylocline. The main morphological character that defines the group is that the receptacular paleae subtend, and more or less enclose, the female florets. The aims of this work are, with the use of three chloroplast DNA regions ( $r p l 32-t r n L$ intergenic spacer, $\operatorname{trn} L$ intron, and $\operatorname{trnL}$-trnF intergenic spacer) and two nuclear DNA regions (ITS, ETS), to test whether the Filago group is monophyletic; to place its members within Gnaphalieae using a broad sampling of the tribe; and to investigate in detail the phylogenetic relationships among the Old World members of the Filago group and provide some new insight into the generic circumscription and infrageneric classification based on natural entities. Our results do not show statistical support for a monophyletic Filago group. The traditional generic circumscription of most of the genera, as well as the traditional infrageneric classification of the genus Filago, do not correlate with the inferred phylogenetic relationships. A monophyletic circumscription of Filago and a new subgeneric treatment for this genus are proposed, this involving description of a new subgenus (Filago subg. Crocidion Andrés-Sánchez \& Galbany, subg. nov.) and four new combinations (Filago subg. Pseudevax (DC.) Andrés-Sánchez \& Galbany, comb. et stat. nov.; Filago discolor (DC.) Andrés-Sánchez \& Galbany, comb. nov.; Filago gaditana (Pau) Andrés-Sánchez \& Galbany, comb. et stat. nov. and Filago griffithii (A. Gray) Andrés-Sánchez \& Galbany, comb. nov.). The genera Cymbolaena, Evacidium and Evax are synonymised under Filago. Several incongruences found between chloroplast and nuclear DNA sequence analyses, as well as a notable degree of intraspecific sequence variation in all regions sequenced are documented and discussed.
\end{abstract}

Keywords Bombycilaena; Cymbolaena; ETS; Evacidium; Evax; intraspecific sequence variation; ITS; Micropus; phylogenetic incongruence; $r p l 32-\operatorname{trn} L ; \operatorname{trn} L-F$

Supplementary Material Figures S1-S4 are available in the free Electronic Supplement to the online version of this article (http://www.ingentaconnect.com/content/iapt/tax).

\section{- INTRODUCTION}

In a revision of the tribe Gnaphalieae based on a morphological-cladistic analysis, Anderberg (1991) described five subtribes, which subsequently appeared to be non-monophyletic based on DNA sequence data (Bayer \& al., 2000, 2002; Ward \& al., 2009). Also, the DNA data did not seem to support some of the generic relationships by Anderberg (Ward \& al., 2009).

Although knowledge of the tribe has increased in recent years, most studies aimed to infer phylogenetic relationships above the generic level within Gnaphalieae based on DNA sequences have been partial and not very successful ones (Ward $\&$ al., 2009). Two previous studies dealing with the molecular phylogeny of Gnaphalieae were based on a worldwide but limited sampling of taxa. Bergh \& Linder (2009) used chloroplast and nuclear DNA sequences and sampled the South African genera rather extensively. Four main clades were inferred: (1) the "Relhania clade", sister to the rest of the tribe, that had been previouly identified by Bayer \& al. (2000) in their phylogeny of the South African Gnaphalieae; (2) the "Metalasia clade" and "Stoebe clade", each comprising almost exclusively Southern African genera; and (3) a large clade called "the rest of Gnaphalieae clade", which comprised some South African genera together with a very limited representation of taxa from Eurasia, America, Australia and New Zealand, and which included the "Australasian clade". A similar pattern was obtained by Ward $\&$ al. (2009) based on sequences of three chloroplast DNA regions. In the latter study sampling of South African genera was more limited, but more American genera were included and sampling of the Australasian genera was largely increased. Again, little resolution was achieved, but two South African basal clades, approximately equivalent to those inferred by Bergh \& Linder (2009), were identified. However, most of the taxa were recovered in a poorly resolved clade, the "crown radiation of the tribe", equivalent to the sum of the "Stoebe clade" and "the rest of Gnaphalieae clade" inferred by Bergh \& Linder (2009). 
The lack of resolution recovered at the suprageneric level within Gnaphalieae suggests a need for increased nucleotide sampling; it may also indicate that the tribe underwent explosive diversification and radiation in a short period of time. Although relationships among genera are not easy to infer, some well supported groups that would correspond to genera, or groups of closely related genera, were recovered by the molecular studies: e.g., Craspedia G. Forst. in Ford \& al. (2007), the "Stoebe clade" and "Metalasia clade" in Bergh \& Linder (2009) and the "Helichrysum-Pseudognaphalium" clade in Ward \& al. (2009). Also, some infrageneric groups within genera have been detected, for example, in Craspedia (Ford \& al., 2007) and in Helichrysum Mill. (Galbany-Casals \& al., 2009).

One group of genera within Gnaphalieae, known as the Filagininae or Filago group, has not yet been included in any molecular phylogenetic study of the tribe. The genera included in this group share several morphological traits: an annual life cycle; leaves alternate or sometimes opposite, sessile, tomentose to villose, eglandular; heterogamous capitula, few together, and often surrounded by a ray of leaves; receptacular paleae arranged in few rows, and often enclosing more or less the female florets; female florets filiform and often outnumbering the hermaphrodite ones, terminally or laterally attached to the achenes; hermaphrodite florets perfect or functionally male; achenes small, oblong, generally laterally compressed; pappus, when present, composed by scabrid bristles (Anderberg, 1991). Most of these annual species grow in open, often disturbed habitats in Mediterranean to semiarid climates, while others prefer more humid and cold-temperate climates, margins of vernal pools or seasonally inundated soils.

These genera have been recognized as a coherent taxonomic unit since Cassini's (1822) description of the group Inuleae-Archetypae comprising on the one hand the Filago group ("I: Clinanthe ordinairement nu sur une partie et squamellé sur l'autre") — made up of the genera Filago L., Gifola Cass., Logfia Cass., Micropus L. and Oglifa Cass. - and, on the other hand, the Inuleae s.str. The generic circumscription of the Filago group has notably changed throughout history to include further genera (e.g., Lessing, 1832; Bentham, 1873; Hoffmann, 1897; Merxmüller \& al., 1977). Anderberg (1991) included ten genera, mainly distributed in Eurasia, northern Africa and northern America: the five monotypic genera Ancistrocarphus A. Gray, Chamaepus Wagenitz, Cymbolaena Smoljan., Evacidium Pomel and Micropus, plus Bombycilaena (DC.) Smoljan. (3 species), Stylocline Nutt. (5 species), Psilocarphus Nutt. (8 species), Logfia (9 species) and Filago (46 species) (see Table 1 for a synopsis of the Filago group sensu Anderberg, 1991, and the main morphological traits and chromosome numbers of each genus).

Some members of this group are mainly known to botanists as examples of anagrams, resulting from Cassini's habit naming new genera based on anagrams of an existing name, for example Logfia, Gifola, Oglifa and Ifloga Cass., which were all based on Filago (Cassini, 1819). Likewise Smoljaninova (1955) used most of the letters of Bombycilaena to name Cymbolaena. The circumscription of most of these genera is confusing and most of the species have been placed under two or more different genera within the group, or even under genera not included in the group. The delimitation of the largest genus, Filago, is probably the most controversial, and the limits among at least three genera (i.e., Filago, Evax Gaertn. and Logfia) have been a matter of frequent discussion. As an example, Smoljaninova (1959) merged Logfia into Filago and maintained Evax as an independent genus; Wagenitz (1969) included Evax and Logfia within Filago and proposed an infrageneric classification for his broad concept of the genus with three subgenera; and Holub $(1975,1976)$ as well as other authors of taxonomic treatments of this group for different Floras (Pignatti, 1982; Alavi, 1983; Valdés \& al., 2002), maintained the traditional use of the three independent genera. Finally, Anderberg (1991) merged into Filago the species traditionally included in Evax, but considered that Logfia posses enough characters to be treated as a distinct genus.

After Anderberg (1991), further investigations resulted in different treatments to certain genera (see Table 1). For example, Morefield (1992) reinstated the genus Hesperevax (A. Gray) A. Gray (H. sparsiflora (A. Gray) E. Greene and H. caulescens (Bentham) A. Gray), and included a third species within it, H. acaulis (Kellogg) E. Greene, in his revision of the genus. However, Anderberg (1991) included these Californian species in Filago. Anderberg (1991) included Diaperia Nutt. in Filago, which was reinstated as an independent genus by Morefield $(2004,2006)$. The genus comprises three species and is distributed in the United States and Mexico. Finally, Morefield (2006) included the two American species of Bombycilaena in Micropus (M. californicus Fischer \& C.A. Mey. and M. amphibolus A. Gray).

The evident instability in the generic and subgeneric classification of the Filago group members reflects the general scarcity of morphological characters traditionally considered relevant for classifying the group, and possibly some degree of homoplasy. Thus, there are not enough morphological characters to provide a satisfactory taxonomic treatment. This mainly affects the generic boundaries and circumscription within the Filago group, but also the infrageneric classification of Filago itself. DNA sequences provide additional independent data for exploring the phylogenetic relationships among taxa, as well as their circumscription. Several cases of incongruence between nuclear and chloroplast phylogenies, caused mainly by hybridization and introgression or by lineage sorting (Okuyama \& al., 2005), have been well documented in the Gnaphalieae (Smissen \& al., 2004; Ford \& al., 2007), which highlights the need to sequence both nuclear and chloroplast DNA in this group.

Based on our field and herbarium observations, hybridization among extant species seems to be very rare, at least among the Old World representatives. In the field, well-differentiated species grow together or nearby without the presence of morphologically intermediate plants. We have examined approximately 15,000 herbarium sheets and found only one clear hybrid (F. vulgaris $\times$ L. arvensis). Wagenitz (1965) also stated that many Filago species are sympatric but well-delimited taxa which are hypothesized to be autogamous or geitonogamous. Cronquist (1950) noticed that in Psilocarphus the wings or apices of the outermost receptacular paleae, which subtend the 


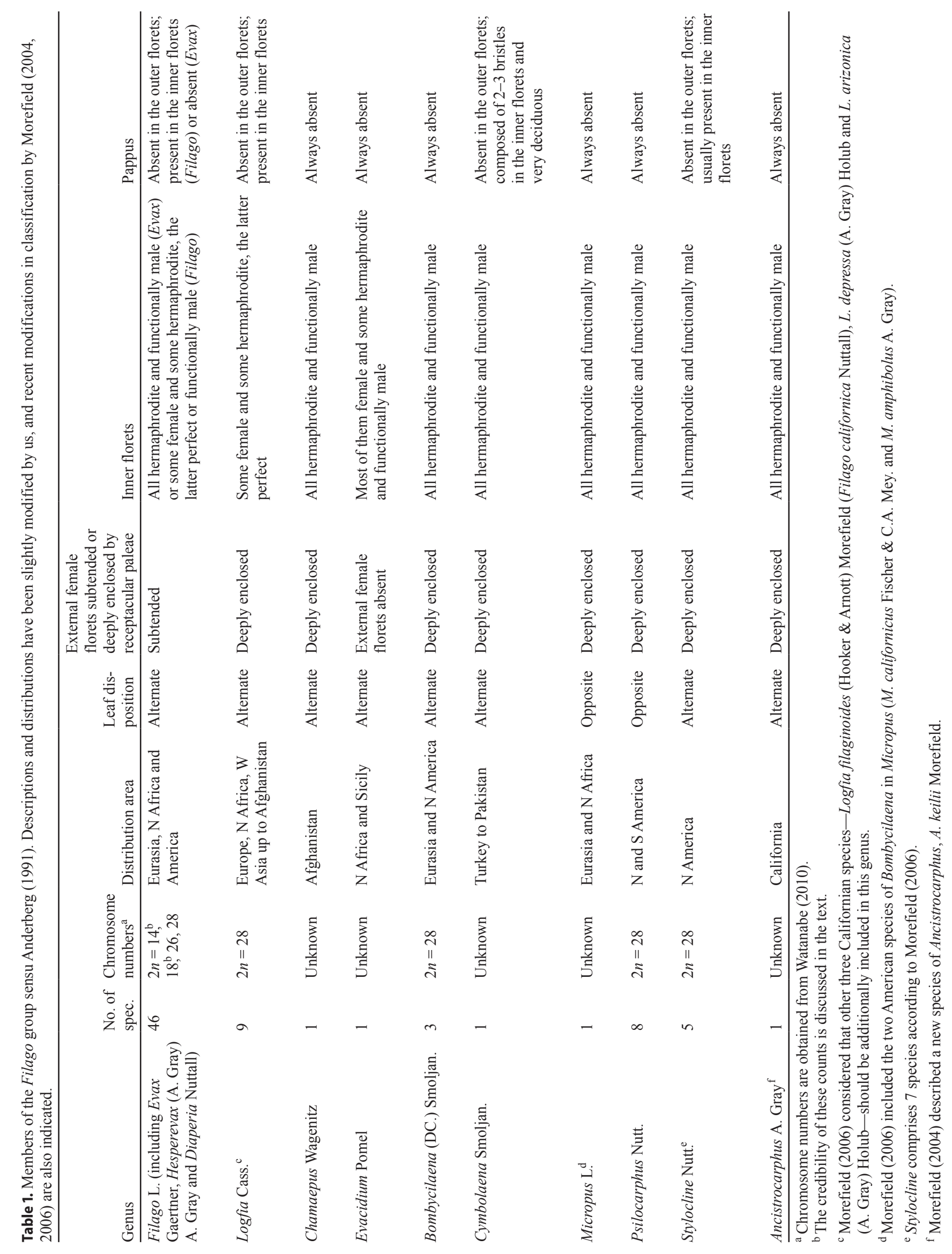


female florets, are incurved during flowering, guiding styles over bisexual or functionally male inner florets. This would probably enforce or obligate within-head geitonogamy. However, Morefield (2006) reported some cases of hybridization among the American taxa of the group. In his opinion, the hypothesized hybrids, when fertile, may easily remain reproductively isolated by the self-pollinating syndrome and become independently reproducing species among their parental taxa.

The aims of the present study are to: (1) test whether the Filago group is monophyletic; (2) determine the position of the group within Gnaphalieae using a broad sampling of the tribe; (3) determine the phylogenetic relationships among the Old World members of the group; and (4) evaluate the importance of hybridization and introgression in the evolution of the group. The study is based on the analysis of sequences of three chloroplast DNA regions (rpl32-trnL intergenic spacer, trnL intron, $\operatorname{trn} L$-trnF intergenic spacer) and two nuclear DNA regions (ITS, ETS).

\section{MATERIALS AND METHODS}

Terminology note. - In this paper we follow Holub (1975) and Morefield (1992) in interpreting the capitular bracts of most of these genera as receptacular paleae, each subtending or enclosing a floret (except in some cases, e.g., Evacidium), instead of considering them true phyllaries. Some genera, such as Micropus, also have true phyllaries, which are completely scarious and highly reduced; they do not subtend florets and are strongly differentiated from the adjacent paleae (Morefield, 1992). Likewise, we have observed in Logfia five small outermost bracts - very much like those present in Bombycilaena and Cymbolaena - that can be easily observed in fruit and are morphologically very different from the receptacular paleae. In our opinion, they should also be interpreted as phyllaries.

Plant material. - We included 60 specimens of the Filago group, representing 42 different species and subspecies, belonging to eight of the ten genera included in this group by Anderberg (1991). Although herbarium material of Ancistrocarphus and Chamaepus was available, amplification was not successful and these two genera were finally not included. We also included two species of Ifloga, one from I. subg. Trichogyne (I. repens (L.) Hilliard) and one from I. subg. Ifloga (I. spicata (Forssk.) Sch. Bip.) (Hilliard \& Burtt, 1981). In order to assess the placement of the Filago group members within the tribe, representatives of 14 different genera were also analyzed, with the intention of including most of the genera of Gnaphalieae native to Eurasia and North Africa, and a selection of genera native to North America and South Africa. No Australasian representatives were included mainly because their very high level of branch length variation makes alignment particularly difficult (R. Smissen, unpub. data). However, preliminary analyses of ETS and trnL-F sequences, which included Pycnosorus globosus Benth., Craspedia variabilis J. Everett \& Doust, Ewartia catipes Beauverd, Stuartina muelleri Sond. and Helichrysum lanceolatum (Buchanan) Kirk. from GenBank, showed that none of these was grouped together with any member of the
Filago group. Finally, three additional representatives of the "Relhania clade" (Relhania L'Hérit., Athrixia Ker Gawl., Leysera L.) were also included to be used as outgroup, following previous works (Bayer \& al., 2000; Bergh \& Linder, 2009; Ward \& al., 2009).

In total, we included in the analyses 82 ITS sequences, of which 76 are new, 82 ETS sequences, of which 81 are new, and $64 \operatorname{trn} L$ intron and $\operatorname{trn} L-F$ intergenic spacer sequences and 79 rpl32-trnL intergenic spacer sequences, all of them new. The voucher data, the source of material and EMBL sequence accession numbers are given in Appendix 1.

DNA extraction, amplification and sequencing. - Total genomic DNA was extracted following the CTAB method of Doyle \& Dickson (1987) as modified by Cullings (1992) from silica-gel-dried leaves collected in the field or herbarium material. For difficult extractions the commercial kits NucleoSpin ${ }^{\circledR}$ Plant (Macherey-Nagel GmbH \& Co. KG, Düren, Germany) and DNeasy extraction Kit (Qiagen Inc., Hilden, Germany) were used, following the manufacturer's instructions.

nrDNA ITS and ETS regions strategies. - The ITS DNA region was amplified using the 17SE forward and the 26SE reverse primers (Sun \& al., 1994). The profile used for amplification using the 17SE/26SE was as described in GalbanyCasals \& al. (2004). Double-stranded PCR products were purified with either the QIAquick ${ }^{\circledR}$ purification kit (Qiagen Inc., Hilden, Germany) or DNA Clean \& Concentrator-5 kit (Zymo Research, Orange, California, U.S.A.), and sequenced with the same primers. Direct sequencing of the amplified DNA segments was performed with a "Big Dye ${ }^{\circledR}$ Terminator v3.1 kit" (Applied Biosystems, Foster City, California, U.S.A.), following the protocol recommended by the manufacturer. Nucleotide sequencing was carried out at the "Serveis Científico-Tècnics" of the University of Barcelona on an ABI PRISM 3700 DNA analyzer (Applied Biosystems). In all cases only one PCR product was obtained and direct sequencing generally produced unambiguous sequences.

The ETS DNA region was amplified using the forward primer ETS1f (Linder \& al., 2000) and reverse primer 18SETS (Markos \& Baldwin, 2001). In some cases, Ast-1 and Ast-2 were also used as internal primers (Markos \& Baldwin, 2001). The profile used for amplification was as described in Galbany-Casals \& al. (2009). Purification and sequencing was performed as for the ITS region, but with the corresponding primers. In all cases, except for Antennaria dioica (L.) Gaertn., only one PCR product was obtained. In this exception, the ETS-PCR product was cloned using the TOPO TA cloning kit (Invitrogen, Carlsbad, California, U.S.A.) following the manufacturer's instructions, except that only half reactions were used. Eight positive colonies were screened with direct PCR using T7 and M13R universal primers, following the amplification profile described in Vilatersana \& al. (2007). All PCR products obtained had the same size. Finally, four PCR products were selected randomly for sequencing in both directions using T7 and M13R primers. All sequences obtained were included in a first analysis. As the four clones formed a highly supported clade and sequence similarity was high, one of them was randomly chosen and used for the final analyses. 
cpDNA regions strategies. - The trnL intron-trnL-F intergenic spacer was amplified using the forward primer trnL-c and reverse primer trnL-f (Taberlet \& al., 1991). The profile used for amplification was as described in Susanna \& al. (2006).

The rpl32-trnL intergenic spacer was amplified using the forward primer rpl32F and reverse primer $\operatorname{trnL}(\mathrm{UAG})$ (Shaw $\&$ al., 2007). The profile used for amplification included $4 \mathrm{~min}$ denaturing at $94^{\circ} \mathrm{C}$, followed by 35 cycles of $60 \mathrm{~s}$ denaturing at $95^{\circ} \mathrm{C}, 90 \mathrm{~s}$ annealing at $52^{\circ} \mathrm{C}$ and $2 \mathrm{~min}$ extension at $72^{\circ} \mathrm{C}$, with an additional final step of $10 \mathrm{~min}$ at $72^{\circ} \mathrm{C}$. Purification and sequencing were performed as for the ITS region, but with the corresponding primers. The rpl32-trnL intergenic spacer could not be sequenced for Diaperia.

Alignments. - Nucleotide sequences were edited using Chromas v.2.0 (Technelysium Pty. Ltd., Tewantin, Australia) and Bioedit v.7.0.1 (Hall, 1999), and aligned with the program ClustalX v.2.0.10 (Thompson \& al., 1997) with subsequent visual inspection and manual revision.

Ambiguous regions in alignments were removed using Gblocks v.0.91 (Castresana, 2000; Talavera \& Castresana, 2007 ) with relaxed conditions in order to preserve as much information as possible: "Minimum Number Of Sequences For A Conserved Position" and "Minimum Number Of Sequences For A Flank Position" were half the number of sequences, "Minimum Number Of Contiguous Nonconserved Positions" was 5, "Maximum Number Of Contiguous Nonconserved Positions" was 10, "Minimum Length Of A Block" was 5, and "Allowed Gap Positions" was "With Half". The percentages of the original datasets that were finally analyzed for each region are shown in Table 2. Data matrices are available on request from the corresponding author.

Analyses. - The evolutionary relationships of the Filago group were examined using two approaches at two different levels. In the first approach (dataset 1) our aim was to place the members of the Filago group within the tribe Gnaphalieae and to test whether they constitute a monophyletic group. For these objectives, the following sequenced DNA regions were used: the ITS, the conserved 3'ETS (which corresponds to the fragment amplified by the Ast-1 and 18S-ETS primers-Markos \& Baldwin, 2001), the trnL intron and the $\operatorname{trnL}-F$ intergenic spacer, and the rpl32-trnL intergenic spacer. For these analyses, the three members of the "Relhania clade" were coded as outgroup taxa (Athrixia phylicoides DC., Relhania pungens L'Hérit., Leysera gnaphalodes (L.) L.).

Our second approach (dataset 2) aimed to investigate the phylogenetic relationships, and generic and infrageneric circumscription within one clade that was a result of the first analyses. This clade contained the Old World members of Filago and Evax, plus Evacidium, Cymbolaena, and the Old World members of Bombycilaena and Micropus, and we will call it hereafter Filago group s.str. In this case, the following sequenced DNA regions were used: the ITS, a longer portion of the ETS [which corresponds to the fragment amplified by the ETS1f(Linder \& al., 2000) and 18S-ETS (Markos \& Baldwin, 2001) primers, and included the more variable $5^{\prime}$ end], and the rpl32-trnL intergenic spacer. Moreover, a larger number of taxa of Filago and Evax were included in this dataset, as well as several specimens per species in a notable number of cases. The trnL-F region was not sequenced for all the specimens and was not included in the analyses in the second approach because the number of informative characters within the Filago group s.str. was very low. Based on the results of the first approach, four species were selected as outgroup taxa for this second approach: Gnaphalium supinum L., Castroviejoa montelinasana (Schmid) Galbany, L. Sáez \& Benedí, Gamochaeta subfalcata (Cabrera) Cabrera and Logfia gallica (L.) Coss. \& Germ.

Maximum parsimony analyses (MP) and Bayesian analyses were performed on the two datasets for each marker independently, and then for the combined nuclear and chloroplast DNA regions (see Table 2). Congruence in the phylogenetic signal of the different DNA regions was tested with the partition homogeneity test (ILD, Farris \& al., 1995a,b). ILD significance values were calculated in TNT v.1.1 (Goloboff \& al., 2003-2005) with the INCTST script—-kindly provided by the authors of the program - with 1000 replicates.

Parsimony analyses involved heuristic searches conducted with PAUP* v.4.0b10 (Swofford, 2002) using TBR branch swapping with character states specified as unordered and unweighted. The indels were coded as missing data. To locate other potential islands of maximum parsimonious trees (Maddison, 1991), we performed 1000 replications with random taxon addition, and also with TBR branch swapping. Only 500 trees were held at each step due to lack of memory. Bootstrap analyses (Felsenstein, 1985) were performed with 1000 replicates, random taxon addition with 20 replicates, and no branch swapping (Lidén \& al., 1997). Bootstrap support (BS) values are shown for nodes with $\mathrm{BS} \geq 60 \%$. For the MP analyses, the consistency index (CI) and retention index (RI) were calculated excluding uninformative characters (Table 2).

Bayesian inference (BI) estimation was calculated using MrBayes v.3.1.2 (Huelsenbeck \& Ronquist, 2001; Ronquist \& Huelsenbeck, 2003). The best-available model of molecular evolution required for Bayesian estimations of phylogeny was selected for each marker using hierarchical likelihood ratio tests (hLRT) and Akaike information criteria (AIC) (Akaike, 1973) as implemented in the software MrModeltest v.2.2 (Nylander, 2004), which considers only nucleotide substitution models that are currently implemented in PAUP and MrBayes v.3.1.2. The best-fitting model for each marker was used in each case for all the analyses (see Table 2), and partitions were defined when necessary in combined analyses. Two simultaneous and independent analyses were performed; for each analysis four Markov Monte Carlo chains were run simultaneously starting from random trees. Each analysis was run for 2,000,000 generations, sampling one out of every 200 generations, which resulted in a total of 10,000 sample trees in each run. It is criti$\mathrm{cal}$ in the Bayesian analysis to ensure that the Markov chain has reached stationarity. Therefore, the first 1000 trees (burn-in) of each analysis were excluded to avoid trees that might have been sampled prior to the convergence of the Markov chains, before computing the majority-rule consensus tree. Posterior probability support (PP) was estimated to be significant for nodes with $P P \geq 0.95$. 
Table 2. Main sequence characteristics and analyses results for the different regions sequences and datasets. The consistency and retention indices

$$
\text { Dataset } 1
$$

\begin{tabular}{|c|c|c|c|c|}
\hline & ITS & 3'ETS & rpl32-trnL & $\operatorname{trn} L-F$ \\
\hline Number of taxa & 64 & 64 & 62 & 64 \\
\hline Sequence length (bp) & $\begin{array}{l}628(\text { L. gnaphalodes }) \\
\text { to } 646(\text { A. margari- } \\
\text { tacea })\end{array}$ & $\begin{array}{l}414(G . \text { uliginosum }) \text { to } \\
436(L . \text { gnaphalodes } \\
\text { and } R . \text { pungens })\end{array}$ & $\begin{array}{l}581 \text { (B. erecta) to } \\
987 \text { (L. gnaphalodes) }\end{array}$ & $\begin{array}{l}775 \text { (H. sparsiflora) to } \\
849 \text { (L. gnaphalodes) }\end{array}$ \\
\hline
\end{tabular}

Aligned length (bp) 665

665

Number of indels (and their length in bp) 27 (1-12)

443

1228

936

Final aligned length after using Gblocks

(\% of the total aligned length) $638(95 \%)$

$$
18(1-9)
$$

$21(1-398)$

$24(1-56)$

Parsimony informative characters

199

$710(58 \%)$

$821(87 \%)$

Number of most parsimonious trees

2573

$420(94 \%)$

127

59

Parsimony
analyses

Number of steps

677

2256

423

108

Consistency index (CI)

0.4963

608

278

97

Retention index (RI)

0.6813

0.4688

0.6295

0.7113

$\mathrm{GTR}+\mathrm{I}+\mathrm{G}$

0.6833

0.8347

0.8814

Bayesian Model of molecular evolution

$\mathrm{GTR}+\mathrm{I}+\mathrm{G}$

inference

(Gu \& al., 1995)

(Gu \& al., 1995)

$\mathrm{GTR}+\mathrm{G}$

(Yang, 1996)

JC (Jukes

\& Cantor, 1969)

\section{RESULTS}

Sequence characteristics and alignments. - Data on sequence length, number and length of required indels, aligned length and final aligned length after applying Gblocks v.0.91 (Castresana, 2000; Talavera \& Castresana, 2007) are given in Table 2.

A certain degree of intraspecific variation was detected in many cases in which several specimens per species were sequenced. In ITS sequences, this ranged from only 1 substitution within Filago duriaei Lange, Filago pyramidata L. and L. arvensis (L.) Holub, up to 9 substitutions and 1 indel within Evax pygmaea (L.) Brot., including subsp. ramosissima (Mariz) R. Fern. \& Nogueira. In ETS sequences, this ranged from 2 substitutions within Evacidium discolor (DC.) Maire, Evax lusitanica Samp., Evax nevadensis Boiss., Filago fuscescens Pomel, Filago micropodioides Lange, $F$. duriaei, and $L$. arvensis, up to 44 substitutions and 2 indels within E. pygmaea, including subsp. ramosissima. In rpl32-trnL intergenic spacer sequences this varied from 1 indel within $F$. fuscescens, $F$. duriaei and $L$. arvensis, up to 6 substitutions and 4 indels within E. pygmaea, including subsp. ramosissima, and Filago desertorum Pomel.

Phylogenetic analyses. - The numerical results of the analyses with all datasets are given in Table 2. Both the parsimony and Bayesian inference analyses showed highly congruent topologies for each marker or combination of markers and for the two datasets. Therefore, we only show Bayesian topologies with the addition of BS values.

Analyses of dataset 1: Relationships within Gnaphalieae and placement of the members of the Filago group. - The ITS and $3^{\prime}$ ETS regions provided similar levels of resolution when they were analysed separately (trees not shown), although the $3^{\prime}$ ETS used in the analyses of dataset 1 was a bit shorter than the ITS due to the impossibility of unambiguously aligning the $5^{\prime}$ portion at the tribal level. The ITS and 3'ETS phylogenies were significantly congruent $(P=0.197)$, and the results will be discussed only for the combined analysis (Fig. S1). In the ITS-3'ETS analyses, following the outgroup clade, a basal clade (clade $1 ; \mathrm{BS}=90 \% ; \mathrm{PP}=1$ ) was recovered within the ingroup, which contained two well-supported clades: one composed of the South African genera Dolichothrix Hilliard \& B.L. Burtt and Lachnospermum Willd. (BS $=99 \% ; \mathrm{PP}=1)$, and the other composed of the two species of Ifloga $(\mathrm{BS}=100 \%$; $\mathrm{PP}=1)$. Lasiopogon Cass. was sister to this 4-species clade but without statistical support. The rest of the species were in a main well-supported clade ( $\mathrm{BS}=96 \%$; PP $=1$ ), which would correspond to the "crown radiation clade" identified by Ward \& al. (2009). This comprised three main clades in our results: one was constituted by the genera Helichrysum, Anaphalis DC. and Pseudognaphalium Kirp. (clade 2; BS $=100 \%$; PP =1); the second one was composed of Syncarpha DC. and Gnaphalium L. (clade 3; $\mathrm{BS}=73 \% ; \mathrm{PP}=1$ ); and the third one comprised the rest of the genera included, except for Vellereophyton Hilliard $\&$ B.L. Burtt $(\mathrm{BS}=63 \% ; \mathrm{PP}=0.98)$, the position of which was not resolved in this analysis. Within the third clade three main supported groups were inferred, although the relative relationships among them are not resolved: one was composed by the American species of the Filago group plus the Old World species of Logfia except for L. arvensis (clade 4; BS = 95\%; PP =1); the second one was composed by Diaperia, Antennaria Gaertn. and Gamochaeta Wedd. (clade 5; BS = no support; PP $=0.99$ ); and the third one was composed of the Old World species of Filago, Micropus and Bombycilaena, plus the monotypic genera Evacidium and Cymbolaena, and L. arvensis (clade 6; $\mathrm{BS}=95 \% ; \mathrm{PP}=1$ ).

Trees resulting from analyses of the trnL intron-trn $L-F$ intergenic spacer (not shown) showed very low resolution in 
are calculated excluding uninformative characters. ${ }^{*}$ denotes considering only the ingroup sequences of dataset 2.

Dataset 2

\begin{tabular}{|c|c|c|c|c|c|c|}
\hline ITS $+3^{\prime}$ ETS & $\begin{array}{l}\text { ITS }+3^{\prime} \mathrm{ETS}+r p l 32- \\
\operatorname{trn} L+\operatorname{trn} L-F\end{array}$ & ITS & ETS & rpl32-trnL & ITS+ETS & $\begin{array}{l}\text { ITS+ETS } \\
+r p l 32-t r n L\end{array}$ \\
\hline \multirow[t]{2}{*}{64} & 62 & 54 & 54 & 52 & 54 & 52 \\
\hline & & $\begin{array}{l}634(F . \text { pyrami- } \\
\text { data) to } 641 \\
(M . \text { supinus })^{*}\end{array}$ & $\begin{array}{l}999 \text { (E. crocidion } \\
\text { and E. nevadensis) to } \\
1012 \text { (B. discolor) }\end{array}$ & $\begin{array}{l}581 \text { (B. erecta) to } \\
845 \text { (C. griffithii) }\end{array}$ & & \\
\hline \multirow[t]{2}{*}{1108} & 3272 & 644 & 1239 & 971 & 1883 & 2854 \\
\hline & & $7(1-4)^{*}$ & $20(1-4)^{*}$ & $13(1-280)$ & & \\
\hline $1058(95 \%)$ & $2589(79 \%)$ & N/A & $1006(81 \%)$ & $778(80 \%)$ & $1650(87 \%)$ & $2428(85 \%)$ \\
\hline 370 & 552 & 55 & 185 & 45 & 240 & 284 \\
\hline 1801 & 49 & 1853 & 94 & 3011 & 16 & 2504 \\
\hline 1305 & 1694 & 122 & 422 & 67 & 548 & 639 \\
\hline 0.4759 & 0.5065 & 0.6066 & 0.5592 & 0.7761 & 0.5657 & 0.5649 \\
\hline 0.6727 & 0.7101 & 0.8339 & 0.7845 & 0.9153 & 0.7934 & 0.7866 \\
\hline $\begin{array}{l}\mathrm{GTR}+\mathrm{I}+\mathrm{G} \\
(\mathrm{Gu} \& \mathrm{al}, .1995)\end{array}$ & $\begin{array}{l}\text { Each region } \\
\text { its model }\end{array}$ & $\begin{array}{l}\text { GTR }+\mathrm{I}+\mathrm{G} \\
(\mathrm{Gu} \& \text { al., } 1995)\end{array}$ & $\begin{array}{l}\text { GTR +I+G } \\
(\mathrm{Gu} \& \text { al., } 1995)\end{array}$ & $\begin{array}{l}\text { GTR }+\mathrm{G} \\
\text { (Yang, 1996) }\end{array}$ & $\begin{array}{l}\text { GTR +I+G } \\
(\mathrm{Gu} \& \text { al., } 1995)\end{array}$ & $\begin{array}{l}\text { Each region } \\
\text { its model }\end{array}$ \\
\hline
\end{tabular}

comparison with the nuclear markers, and the results showed some incongruities in the topology in relation to the ITS-3'ETS analyses: Vellereophyton was grouped together with the genus Gnaphalium (BS $=67 \%$; $\mathrm{PP}=1$ ). Lasiopogon was placed within the "crown radiation" and the "Lachnospermum-Dolichothrix clade" was not grouped with the "Ifloga clade". The results of the ILD test reported significant incongruities between the trnL-F region and the nuclear (ITS+ETS) DNA regions $(P=0.001)$.

The fragment of the rpl32-trnL intergenic spacer used for this analysis had more than twice the amount of informative characters than the previous chloroplast region (Table 2), although the size of the fragment used here was shorter than in the previous case, because alignment of large imperfect indels could not be unambiguously achieved. Thus, almost half of the region was excluded from our analyses. The analyses of this region (Fig. S2) supported clade $2(\mathrm{BS}=93 \%$; $\mathrm{PP}=1)$, clade $4(\mathrm{BS}$ no support; $\mathrm{PP}=1)$, and clade $6(\mathrm{BS}=71 \%$; $\mathrm{PP}=1)$. Initial alignments and analyses suggested two clear groups of haplotypes within clade 6: one was composed by Evacidium discolor, Evax nevadensis, Filago hispanica (Degen \& Hervier) Chrtek \& Holub, Logfia arvensis, Cymbolaena griffithii (A. Gray) Wagenitz, Filago paradoxa Wagenitz and the genus Bombycilaena; and the second one by the rest of the species (not shown). However, most of these differences could be attributed to a single $9 \mathrm{bp}$ inversion that the species listed above have in comparison with all other members of the tribe included. Bombycilaena, instead, presents a larger deletion affecting the region where the inversion is found. Final analyses excluded the region affected by this inversion, as it was noticeably altering the topologies obtained.

Finally, some incongruences were detected in relation to the results obtained from the nuclear regions: Micropus supinus was placed here within clade 4 instead of within clade
6. Moreover, Vellereophyton was grouped with the genus Gnaphalium (BS $=99 \%$; $\mathrm{PP}=1$ ) as in the $t r n L-F$ region analyses, while the position of Syncarpha remained unresolved. The results of the ILD test also showed significant incongruities between the rpl32 region and the nuclear (ITS +ETS) DNA regions $(P=0.001)$.

Despite the incongruities detected by the ILD test, also between the two cpDNA regions and the two nDNA regions analysed together $(P=0.001)$, the four regions were combined. The analyses (Fig. 1) recovered the same clades described for the ITS-3'ETS combined analyses, with the exception of clade 3 , which in the combined analyses was composed by Gnaphalium and Vellereophyton, as in the analyses of the chloroplast regions.

Analyses of dataset 2: Relationships within the Filago group s.str. - The separate analyses of the ITS and ETS regions for this dataset (not shown) did not show any incongruence in the topology, so the main results will be discussed only for the ITS-ETS combined analyses (Fig. S3). In addition, the ILD results showed significant congruence of the two datasets $(P=0.353)$. It is worth noting that in the separate analyses, the level of resolution provided by the longer portion of the ETS analysed was significantly higher than the resolution provided by the ITS region. The combined ITS-ETS analysis (Fig. S3) gave high support to the ingroup $(\mathrm{BS}=99 \%$; $\mathrm{PP}=1)$ and showed M. supinus as sister to the rest of the species, which were grouped together in a main clade with little support (BS $=73 \%$; $\mathrm{PP}=$ no support). Within this main clade, nine wellsupported clades were recovered (A-I), which will be discussed in detail in the Discussion.

Initial analyses of the rpl32-trnL intergenic spacer showed the same two different types of haplotypes differing in a $9 \mathrm{bp}$ inversion (not shown). Evax crocidion Pomel, as well as other additional specimens of Filago hispanica, Evax nevadensis, 
Evacidium discolor and Logfia arvensis included in dataset 2, also presented the inversion. Final analyses excluded the region affected by the inversion. This marker showed three notable incongruities in relation to the nrDNA analyses (Fig. S4): $\mathrm{Mi}$ cropus supinus was not placed within the ingroup taxa but grouped with $L$. gallica, in the outgroup taxa (BS $=99 \%$; PP $=1$ ), as previously observed in the analyses of dataset 1 ; both the clade composed by E. crocidion and E. nevadensis (clade E), and that grouping Bombycilaena (clade A) were related to different species in the nuclear and chloroplast DNA analyses. The results of the ILD also showed significant incongruities between the rpl32 region and both nrDNA regions $(P=0.001)$.

The supported clades recovered in the cpDNA and nuclear DNA combined analyses (Fig. 2) were mainly those described
Fig. 1. Consensus phylogram obtained from the Bayesian analysis of ITS $+3^{\prime}$ ETS $+r p l 32$-trn L intergenic spacer + trnL intron + trn $L-F$ intergenic spacer sequences (dataset 1). Bayesian posterior probabilities $\geq 0.95$ are shown below branches. Bootstrap values $>60 \%$ from the parsimony analyses are shown above branches. Numbers to the right and informal names of groups in bold font indicate clades discussed in the text.

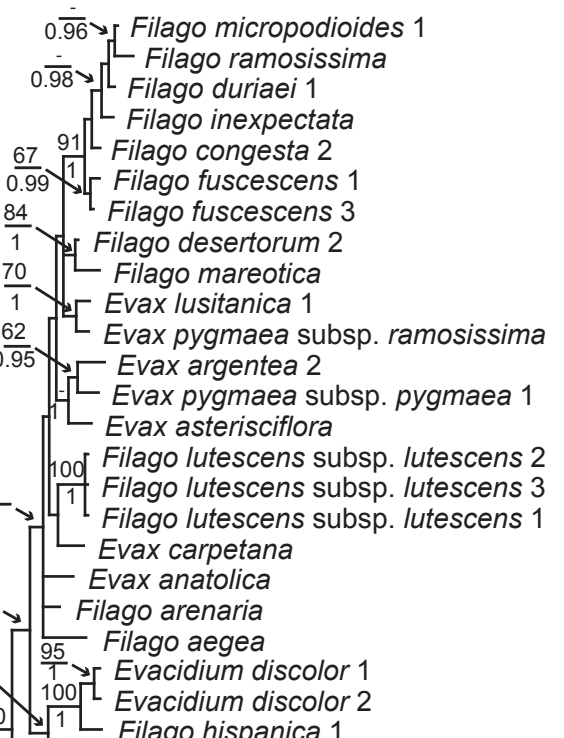

1 $y$ Filago lutescens subsp. lutescens 1

$84 \quad$ Evax anatolica

17 - Filago arenaria

$\frac{61}{1} \sqrt{1}$ ¿ Evacidium discolor 1

Evacidium discolor

Evax nevadensis 1

99 Filago paradoxa

$100-1$ Logfia arvensis 2

$1-$ Cymbolaena griffithi

100 - Bombycilaena discolor 2

Bombycilaena erecta

Micropus supinus

"Filago group"

(sensu Anderberg 1991)

Filago arizonica

1 - Filago depressa

$0 . \overline{9}=\sqrt{1}$ L Filago californica

$0 \overline{\overline{9}} \div$ - Stylocline psilocarphoides

- Micropus californicus

0.97 1 1 Psilocarphus brevissimus

Hesperevax sparsiflora

Logfia clementei

${ }_{98} \sqrt{-}$ Logfia gallica

1 - Logfia minima

$\overline{0.96}-{ }^{-}$Logfia heterantha

Gnaphalium supinum

Castroviejoa montelinasana

Gamochaeta subfalcata

Antennaria dioica Leontopodium alpinum

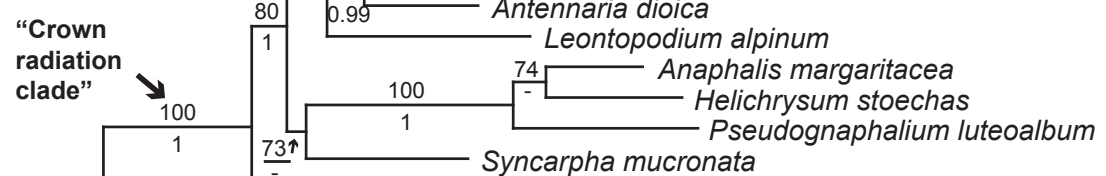
Gnaphalium austroafricanum Vellereophyton dealbatum 
for the ITS and ETS combined analyses. In Fig. 2, the generic and subgeneric classification proposed by Wagenitz (1969) is compared with that proposed by Holub $(1975,1976)$, which is represented by the names used in the tree. The names in parentheses are those we consider correct according to the taxonomic treatment derived from our results (including three new combinations at the species level that are proposed in the present paper), and have only been added when they differ from those proposed by Anderberg (1991) or Holub $(1975,1976)$. A new generic and subgeneric classification is also proposed (see Table 3, Appendix 2, and Andrés-Sánchez \& al., submitted).

\section{DISCUSSION}

Phylogenetic relationships in Gnaphalieae and placement of the members of the Filago group. - In the analyses of Gnaphalieae some main clades equivalent to those found in previous phylogenies (Bergh \& Linder, 2009; Ward \& al., 2009) were inferred (Figs. S1-S2; Fig. 1). The genus Ifloga was grouped with the members of the "Metalasia clade" included in the analyses, and was not closely related to any of the Filago group members, even though it was first included in the subtribe Filagininae by Bentham (1873) and Schultz Bipontinus (1845) due to the capitula morphology. However, Filago group members and Iflog $a$ also show some morphological differences: pappus bristles that are apically plumose in Iflog $a$ and scabrid in the Filago group; synflorescences consist in a few capitula together arranged along an axis in Iflog $a$, whereas the capitula are generally arranged in glomerules in the Filago group; and their chromosome numbers are also different, $2 n=14$ in Iflog $a$, while they are usually $2 n=28$ (rarely $2 n=26$ ) in the Filago group. Leins (1973) showed that the pollen grains in Ifloga are on average smaller and less spiny and the style is less divided than in the Filago group members. According to this author, Ifloga would be more closely related to Stoebe L. or Disparago Gaertn. than to any of the Filago group members. This was also indirectly proposed in the subtribal treatment by Hilliard \& Burtt (1981). Therefore, it seems that the similarity in the capitula structure between Filago and Ifloga is only superficial and not a product of common ancestry, but rather of independent convergent evolution.

Within the "crown radiation" clade, which showed low resolution and lack of structure in previous phylogenies (Bergh \& Linder, 2009; Ward \& al., 2009), we detected a higher degree of structure by using the ITS and rpl32-trnL intergenic spacer, and a combination of a larger number of characters than in previous works (Fig. 1). Clade 2 was composed by Anaphalis, Helichrysum and Pseudognaphalium and showed the maximum statistical support, which confirms that it is necessary to study these genera together (Ward \& al., 2009). Clade 3 (Fig. 1) grouped together Gnaphalium austroafricanum Hilliard, endemic to southern Africa, and Gnaphalium uliginosum L., a Eurasian species. This therefore seems to be another example of dispersal from southern Africa to the Mediterranean area, in addition to those discussed by Bergh \& Linder (2009) for the tribe.
The next subclade within the "crown radiation clade"which we will call from now on the "FLAG clade" for Filago, Leontopodium, Antennaria and Gamochaeta, some of the largest genera that compose it - grouped together several genera mainly distributed in Eurasia, North Africa and the American continent (Fig. 1), although Plecostachys serpyllifolia (Berg.) Hilliard \& B.L. Burtt, from South Africa, could also belong to this clade according to Bergh \& Linder's (2009) phylogeny. Members of the "FLAG clade" have a base chromosome number of $x=14$ (or $x=13$ in some Filago), in contrast with members of clades 2 and 3, which have a base number of $x=7$; however, some exceptions to this can be found. There is one count of $2 n=14$ for Diaperia candida (Torr. \& A. Gray) Benth. \& Hook. f. (Keil \& Pinkava, 1976), although some doubts have been expressed regarding its accuracy (Morefield, 2006). Unfortunately, this particular species of Diaperia was not included in our analyses, so its phylogenetic position remains unknown. There is also one count of $2 n=14$ for Leontopodium alpinum Cass. from India (Mehra \& Remanandan, 1975), but no voucher was cited, and given that this species does not grow in India we also consider it doubtful. Finally, a surprising count of $2 n=18$ for Evax pygmaea (Humphries \& al., 1978) could be a print mistake, since other counts reported for this species indicate $2 n=26$ or 28 .

Within the "FLAG clade" (Fig. 1), we found three main groups, although neither the relationships among them nor their closest relatives within the tribe could be identified. The first one (clade 4) comprised the American members of the Filago group, including Micropus californicus, Stylocline, Psilocarphus, Hesperevax, and the American species of Filago, plus the Old World members of Logfia. The second one (clade 5) included Antennaria and Gamochaeta. Diaperia, which was only included in the nrDNA analyses, appeared related to these two genera (Fig. S1, clade 5) in this analysis. These results suggest that Diaperia is not closely related to Evax as Morefield $(2004,2006)$ hypothesized, or to any other genus from the Filago group. The third clade (clade 6) comprised the Old World members of Filago, Evax, Cymbolaena, the "L. arvensis complex", Bombycilaena and Micropus, which we have called the Filago group s.str.

These results show that the Filago group as previously circumscribed (Fig. 1, clades $4+6$ ) has no statistical support, so that the genera included could have had two independent origins. However, although there is no support, the combined analyses show a sister relationship between clades 4 and 6 (Fig. 1), which could indicate that there is a closer relationship between these two clades than with other genera within the "FLAG clade". The high morphological similarity of several characters of the capitula in Bombycilaena, Micropus and Logfia-like the external receptacular paleae coriaceous in fruit that deeply enclose the female florets, and the external female florets with the corolla laterally attached to a reniform achene-would also support this hypothesis (Table 3).

The composition of clade 4 would support Morefield's opinion (2006) that the American species of Filago should be included in the genus Logfia, and would also support Anderberg's (1991) idea that Logfia and Filago should be considered independent genera (Table 1). Nevertheless, according to our 


\author{
Wagenitz's (1969) classification \\ - Filago subg. Filago sect. Filago \\ - Filago subg. Filago sect. Evacopsis \\ Filago subg. Filago sect. Filaginoides \\ Filago subg. Filago sect. Gifolaria \\ Filago subg. Evax \\ Filago subg. Oglifa
}

Holub's $(1975,1976)$ classification

Present proposal

Filago congesta 2

Filago congesta 1

Filago inexpectata

Filago fuscescens 2

Filago fuscescens 1

Filago fuscescens 3

Filago pyramidata 2

Filago pyramidata 1

Filago duriaei 2

Filago duriaei 1

Filago micropodioides 1

Filago ramosissima

Evax argentea (Filago argentea) 2

Evax pygm. subsp. pygm. 1 (Filago pygmaea)

Evax asterisciflora (Filago asterisciflora)

Evax pygm. subsp. pygm. 1 (Filago pygmaea)

Evax argentea (Filago argentea) 1

Evax lusitanica 1 (Filago lusitanica)

Evax lusitanica 2 (Filago lusitanica)

Evax pygm. subsp. ram. (Filago gaditana)

Evax carpetana (Filago carpetana)

Filago desertorum 1

Filago mareotica

Filago desertorum 2

Filago lutescens subsp. lutescens 1

Filago lutescens subsp. lutescens 3

Filago lutescens subsp. lutescens 2

Filago lutescens subsp. atlantica

Filago aegea

Filago eriocephala

Filago vulgaris

Evax anatolica (Filago anatolica)

Filago arenaria

Evax nevadensis 1 (Filago nevadensis)

Evax nevadensis 2 (Filago nevadensis)

Evax crocidion (Filago crocidion)

Evacidium discolor 1 (Filago discolor)

Evacidium discolor 2 (Filago discolor)

Filago hispanica 1

Filago hispanica 2

Logfia arvensis 2 (Filago arvensis)

Filago paradoxa

Logfia arvensis 1 (Filago arvensis)

Cymbolaena griffithii (Filago griffithii)

Bombycilaena discolor 2

Bombycilaena discolor 1

Bombycilaena erecta

Micropus supinus

Gnaphalium supinum

- Logfia gallica

Gamochaeta subfalcata

Castroviejoa montelinasana

Fig. 2. Consensus tree obtained from the Bayesian analysis of ITS + ETS + rpl32-trnL intergenic spacer (dataset 2). Bayesian posterior probabilities $\geq 0.95$ are shown below branches. Bootstrap values $>60 \%$ from the parsimony analyses are shown above branches. Wagenitz's (1969), Holub's $(1975,1976)$ and our present classification are compared. Letters in bold font indicate clades discussed in the text. 
data, there should be one exception to Anderberg's delimitation of Logfia, that of L. arvensis, as this species was clearly placed within the "true" Filago instead of within Logfia (Fig. 1) (see below for further details).

Clade 4 was divided into two main clades (Fig. 1), one was composed of the species of Logfia widely distributed in Eurasia and North Africa, and the other clustered together all the North American species from the Filago group included in our sampling. This indicates that one of these groups could have derived from the other after a single colonization event, probably through the Bering Strait, although from our results the direction of this dispersal event cannot be deduced. Wind dispersal does not seem improbable for the light seeds, accompanied by the coriaceous enclosing paleae, which could be replacing the pappus (usually missing) in this function, as suggested by Cronquist (1950). Moreover, birds seem to harvest shoots of Logfia, Micropus, Psilocarphus and Stylocline species, presumably for nesting materials, which may also contribute to dispersal of some taxa (Morefield, 2006).

Finally, in clade 4, Hesperevax sparsiflora was also placed within the American group, and therefore is apparently not related to the Old World Evax. This result is in agreement with Morefield's (1992) opinion that this species was deviant within that genus.

Our results also show that Micropus californicus, sometimes included in Bombycilaena (e.g., Holub, 1998), is not closely related to any of the Old World members of either of these two genera (Fig. 1). Considering that the type of Micropus is M. supinus, and also that the type of Bombycilaena is B. erecta (L.) Smoljan., the taxon named here M. californicus should probably be transferred to a different genus from among those within the clade where it is placed. However, a detailed phylogeny including a more comprehensive sampling of the American genera is needed before making a firm decision.

In addition, it is worth noting here that M. supinus was strongly grouped (Fig. S2) with Logfia in the rpl32-trnL intergenic spacer analyses, instead of with the Old World members of the Filago group as it was in the nuclear DNA analyses (Fig. S1). The analyses of the $\operatorname{trn} L-F$ region also excluded this species from the Old World Filago group, although its position was not resolved. This incongruence between the nuclear and chloroplast DNA analyses suggests that these two independently inherited DNA types may not share a common evolutionary history for this taxon. As stated in the Introduction, it is our opinion that contemporary hybridization does not seem common in this group, although Morefield (2006) reported some cases among the American taxa. In cases similar to this, historical gene flow between species that currently show strong reproductive barriers (Cronn \& Wendel, 2004 and references therein) has been hypothesized, and this could also be the case within these predominantly autogamous or geitonogamous genera. Under this hypothesis, M. supinus could have originated by ancient homoploid hybridization between a hypothetical ancestor close to Logfia and a hypothetical ancestor close to Filago or Bombycilaena, although lineage sorting could also be a credible cause for this incongruence. The combined analyses using all the regions sequenced (Figs. 1-2) showed M. supinus at the base of the Filago group s.str., as in the ITS-ETS combined analyses. This is probably due to the number of informative substitutions, which was higher in the nuclear sequences than in the chloroplast DNA sequences.

Finally, although the position of Leontopodium alpinum, Castroviejoa montelinasana and Gnaphalium supinum within the "FLAG clade" was not resolved, an important conclusion can be derived from our analyses: the presence of G. supinum within this clade, and not with the other two species of Gnaphalium sampled (Fig. 1), supports previous opinions about the heterogeneity of this probably unnatural genus. Actually, G. supinum is sometimes included in Omalotheca Cass. (e.g., in Holub, 1976). Anderberg (1991) included it in Gnaphalium, although he also expressed doubts about the monophyly of this large genus and the need for further study.

Phylogenetic relationships and systematics of the Filago group s.str.: Taxonomic implications. - The combined analyses of dataset 2, which corresponds to the above mentioned Filago group s.str., showed a sister-group relationship between Micropus supinus and the rest of the species (Fig. 2). However, as it has also been mentioned, the analyses of the rpl32-trnL intergenic spacer alone placed this species with the outgroup (Fig. S4). In our opinion, given its rather isolated position and its particular morphological features - opposite leaves and the particular appendices of its receptacular paleae-Micropus should be considered an independent monotypic genus.

Bombycilaena was recovered as a monophyletic genus (Figs. S3-S4; Fig. 2; clade A). While this genus was placed within the main Filago clade in the rpl32-trnL intergenic spacer analyses (Fig. S4), the nrDNA and the combined analyses (Fig. S3; Fig. 2) show it as sister to a main clade which includes all the Old World species of Filago (including the type species of the genus, $F$. pyramidata) plus $E$. discolor, $C$. griffithii, the genus Evax, and Logfia arvensis. All these taxa (up to four genera) appear within this main Filago clade (Fig. 2, clades B-I; BS = $78 \%$; $\mathrm{PP}=1$ ) and from our point of view all of them should be included in a wide genus Filago (Table 3). Although the consensus analyses lacks resolution (Fig. 2), a broad genus Filago excluding Bombycilaena receives high support values in the nrDNA analysis (Fig. S3; clades B-I; BS $=95 \%$; PP = 1). Based on this and on a set of morphological characters (i.e., receptacular paleae coriaceus in Bombycilaena while scarious in Filago; corolla of the external female florets laterally attached to a virguliform achene in Bombycilaena while apically attached to an oblong achene in Filago) we exclude Bombycilaena from Filago. Also nomenclatural stability and simplicity are best served in this way, as no additional new combinations under Filago are needed for the species included in Bombycilaena.

According to our results (Fig. 2), several groups can be traced within Filago, but they do not correspond to any of the generic treatments and infrageneric categories proposed up to now in the delimitation of Filago, Evax and Logfia. Table 3 shows a comparison of the two main previous taxonomic classifications (Wagenitz, 1969; Holub, 1975, 1976) with our present proposal derived from this study, as well as information on the morphological characters of the genera and infrageneric categories, and on the distribution of the species studied. 


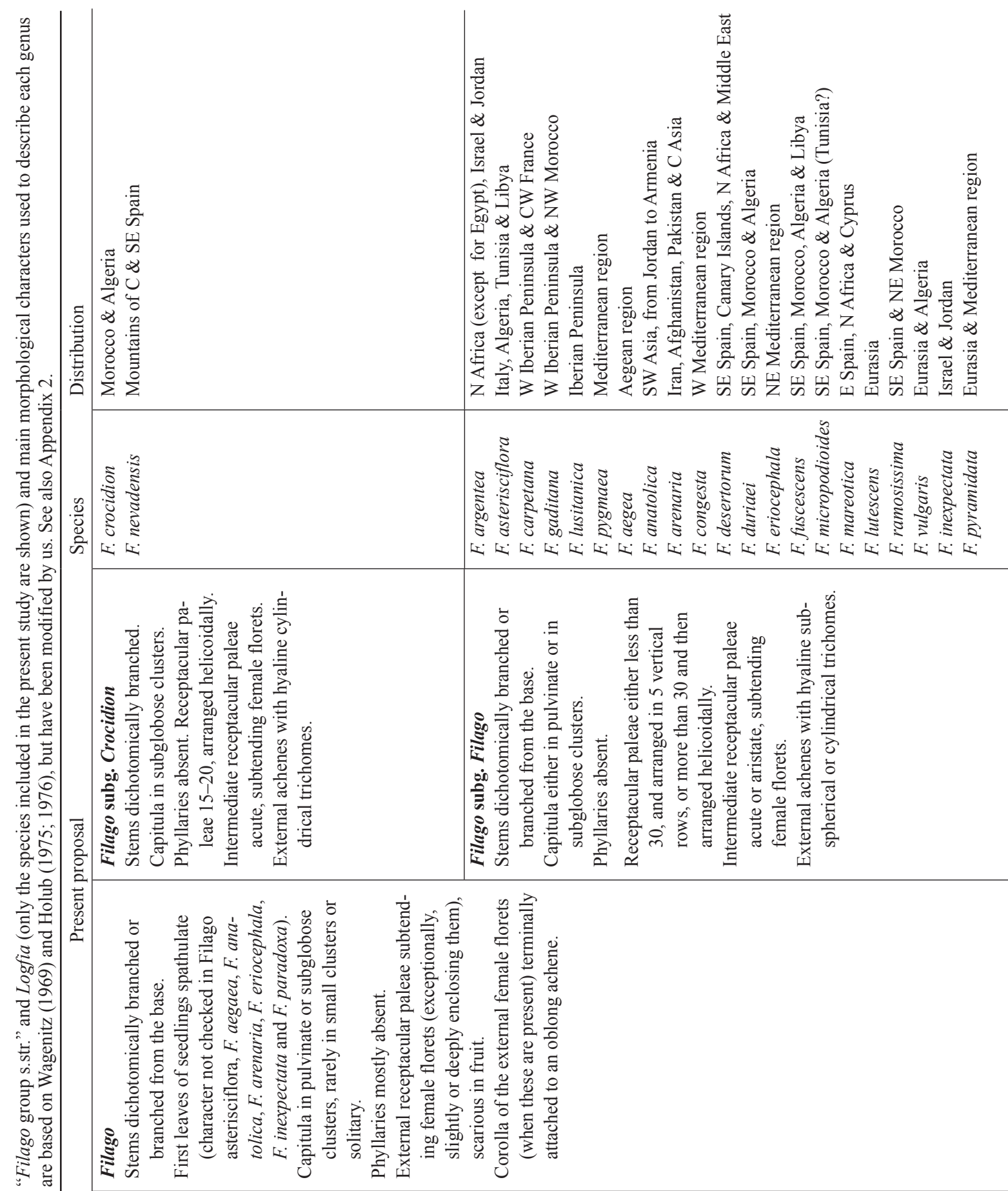




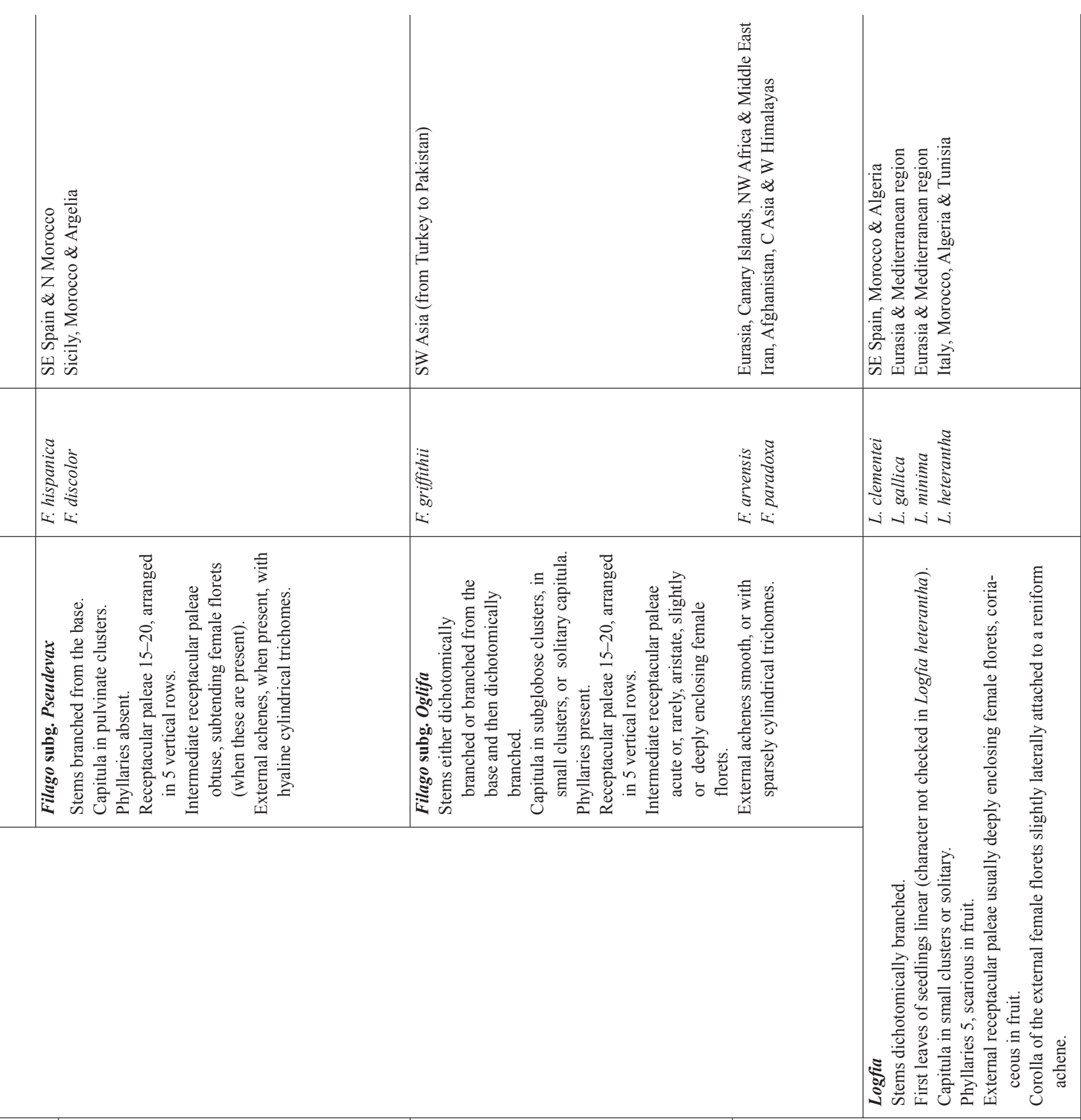

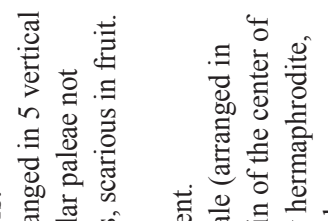

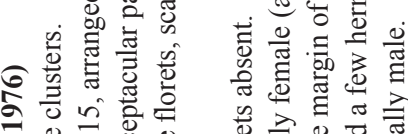

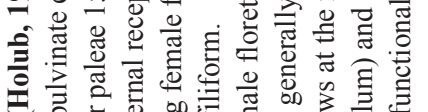

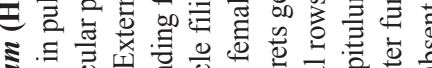

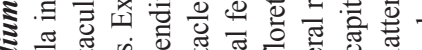

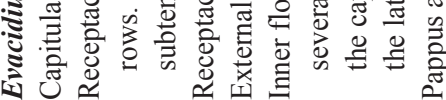

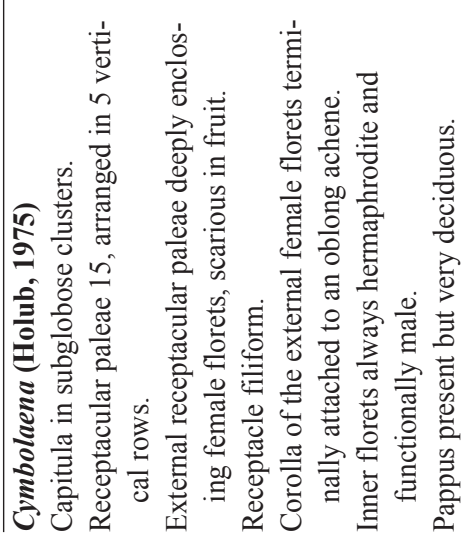


Clade B (Fig. 2; BS $=100 \%$; PP = 1) was sister to the rest of Filago and contained F. paradoxa, L. arvensis and C. griffithii (Fig. 3A, as F. griffithii), which we propose to classify under Filago subg. Oglifa (Cass.) Gren. (Table 3), characterized by the achenes of the external florets being smooth, or with sparsely cylindrical trichomes, and the external receptacular paleae slightly or deeply enclosing female florets. Traditionally,
L. arvensis (Fig. 3B, as Filago arvensis) has been included within genus Logfia mainly based on two morphological characters: the capitula are solitary or arranged in small clusters and there are three receptacular paleae per vertical row. However, although the external receptacular paleae slightly enclose the female florets, they do not enclose them deeply as in the remaining species of Logfia. In addition, in L. arvensis these
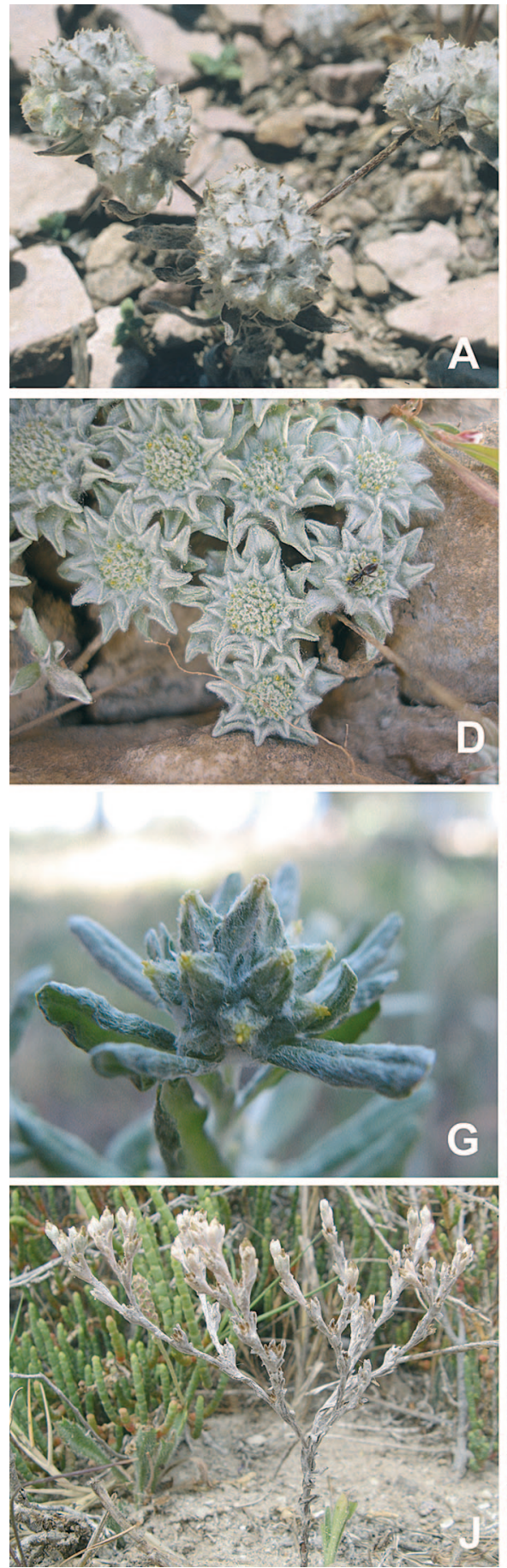
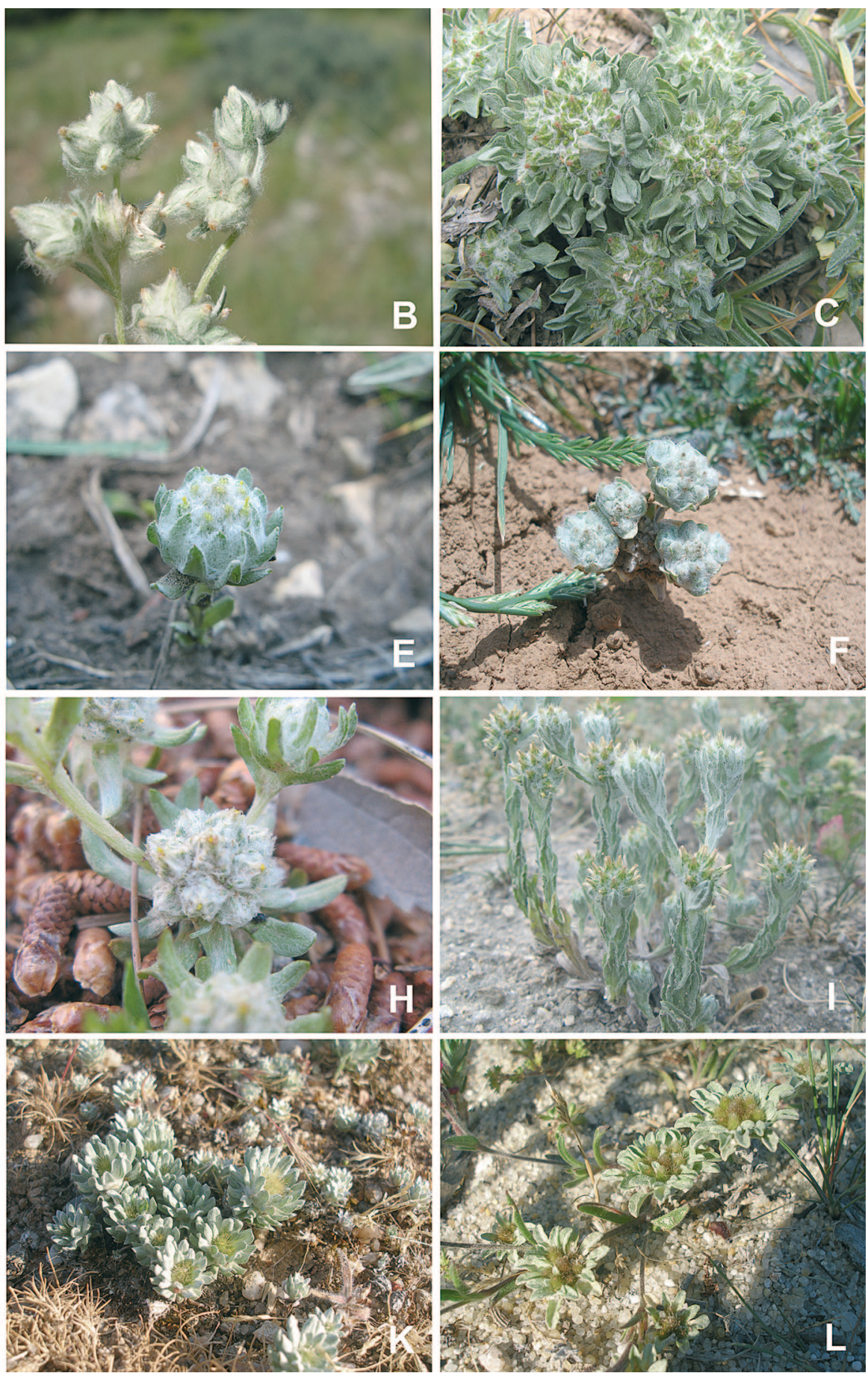

Fig. 3. Morphological diversity in genus Filago. F. subg. Oglifa: A, F. griffithii; B, F. arvensis. F. subg. Pseudevax: C, F. discolor; D, F. hispanica. F. subg. Crocidion: E, F. nevadensis; F, F. crocidion. F. subg. Filago: G, F. duriaei; H, F. micropodioides; I, F. vulgaris; J, F. mareotica; K, F. pygmaea; L, F. gaditana. 
external receptacular paleae are scarious in fruit (instead of coriaceous, as in the rest of the species of Logfia) and the corolla of the external female florets is terminally attached to an oblong achene, while this corolla is more or less laterally attached to a reniform achene in the rest of the species of Logfia (Table 3). These latter characters further support the inclusion of L. arvensis in Filago, as it was described for the first time by Linnaeus (1753), which is in agreement with our molecular results. Filago paradoxa appeared nested within the two samples of $L$. arvensis included in our analysis and no resolution was found for them. Further studies are needed to go deeper into the taxonomy and systematics of this group, as both species are morphologically very similar.

Based on the morphology of the external receptacular paleae (deeply enclosing the female florets), Cymbolaena has traditionally been considered to be more closely related to Micropus than to Filago, and even included in Micropus (i.e., Boissier \& Reuter, 1875; Smoljaninova, 1955). Nevertheless, it shares several characters with Filago (Table 3), such as scarious external receptacular paleae in fruit and the fact that the corolla of the external female florets is terminally attached to an oblong achene. These two characters support the inclusion of this species in Filago (Appendix 2).

Clade C (Fig. 2; $\mathrm{BS}=99 \%$; PP = 1) contained E. discolor (Fig. 3C, as Filago discolor) and F. hispanica (Fig. 3D). These two species show morphological characters that have been considered to be typical of Filago (e.g., less than 30 receptacular paleae arranged in 5 vertical rows) and others traditionally used to characterize Evax (e.g., pulvinate clusters of capitula) (Table 3). In addition, both species have external obtuse receptacular paleae, truncate in $E$. discolor and cucullate in F. hispanica. Based on molecular data and morphology, we propose here to group these species in a new subgenus, Filago subg. Pseudevax (DC.) Andrés-Sánchez \& Galbany, comb. et stat. nov. (Appendix 2).

Clade E (Fig. 2; $\mathrm{BS}=100 \%$; $\mathrm{PP}=1$ ) comprised two specimens of E. nevadensis (Fig. 3E, as Filago nevadensis) and one of E. crocidion (Fig. 3F, as Filago crocidion), which corresponds with the high morphological similarity of these two species. Clade $\mathrm{E}$ was grouped with clade $\mathrm{C}$ with high support in the rpl32-trnL intergenic spacer analyses (Fig. S4; BS = 94\%; PP = 1 ), whereas its position in a very long branch was highly supported in a different group (close to clade D) in the ITS + ETS analyses, although their closest relatives were not resolved (Fig. S3). Again, this incongruence between the different inherited types of DNA may be showing either hybridization or lineage sorting. Present hybridization events do not seem to be a plausible explanation because the incongruence involves several specimens of two different species, and also due to the observed absence of hybrids within this group. There is no evidence of present intraspecific cpDNA polymorphism involving the two different haplotypes, which makes persistence of ancestral polymorphism and lineage sorting also improbable. Ancient hybridization would then be the most plausible explanation. An ancestor of $F$. hispanica and $E$. discolor could have been one of the parental taxa involved in a hypothetical hybrid origin of the ancestor of E. nevadensis and E. crocidion, since their present geographic areas in the SE Iberian Peninsula and NW
African mountains are spatially close. The other parental taxon involved in this hypothetical hybridization is not clear since the resolution is not high enough at this level in the analyses of the nuclear regions. We propose the new Filago subg. Crocidion Andrés-Sánchez \& Galbany, subg. nov. (Appendix 2) for these two species, morphologically characterized by capitula in subglobose clusters and 15 to 20 receptacular paleae-both character states typical of the traditional genus Filago-but these receptacular paleae are arranged helicoidally, as in the species traditionally included under Evax (Table 3).

Clades D and F-I (Fig. 2) would constitute a broad subgenus Filago, including Evax anatolica Boiss. \& Heldr., and Filago arenaria (Smoljan.) Chrtek \& Holub, although the position of these two species was not resolved in our analyses. Evax anatolica was included in F. sect. Filaginoides (Smoljan.) Wagenitz (Wagenitz, 1969) together with $F$. hispanica (Fig. 3D) and other species not included in our study. Our results show that this section is not monophyletic and that the resemblance between the two species (F. hispanica, E. anatolica) is probably a product of parallel evolution affecting several morphological characters. Wagenitz (1969) included $F$. arenaria in $F$. sect. Evacopsis (Pomel) Batt. together with Filago congesta Guss. ex DC., Filago inexpectata Wagenitz, F. duriaei (Fig. 3G) and F. micropodioides (Fig. 3H). In our trees these latter species were all part of clade I (Fig. 2), while $F$. arenaria was weakly grouped with clade $\mathrm{D}$, indicating that $F$. sect. Evacopsis is not monophyletic.

Clade D comprised Filago aegaea Wagenitz, Filago eriocephala Guss. and F. vulgaris Lam. (Fig. 3I). The latter species has traditionally been considered closely related to F. pyramidata and included within the so-called "Filago germanica group". They were even considered the same species by Linnaeus (1753) in the "Addenda post indicem", as well as by other later authors (e.g., Bolòs \& Vigo, 1996 treated F. vulgaris as F. pyramidata subsp. canescens (Jord.) O. Bolòs \& Vigo). Regardless of their morphological similarities (25 to 30 receptacular paleae arranged in 5 vertical rows, inner florets both female and hermaphrodite, all of them with pappus), our results strongly indicate that they are clearly different and unrelated species. They differ in that $F$. vulgaris (as well as the morphologically similar $F$. eriocephala) has lanceolate leaves and very dense glomerules composed of more than 30 capitula (Fig. 3I), whereas $F$. pyramidata has obovate leaves and laxer glomerules composed of less than 30 capitula.

Clade $\mathrm{F}$ comprised $F$. desertorum and $F$. mareotica Delile (Fig. 3J), two morphologically divergent species, with coincident distribution areas (Table 3), but very different in their ecological preferences: $F$. desertorum grows in semiarid environments, and $F$. mareotica grows in saline maritime environments. The closest relatives of these species could not be determined from our results.

Clade G comprised the four specimens of Filago lutescens Jordan included in our study, with a specimen identified as F. lutescens subsp. atlantica Wagenitz as sister to the rest. This may be evidence of some genetic differences between these two taxa which are morphologically distinct, although the distribution ranges of the latter subspecies and the typical range overlap in the southwest of the Iberian Peninsula. In some 
Floras (e.g., Bolòs \& Vigo, 1996), F. lutescens has been treated as a subspecies of $F$. pyramidata, but our results show that it does not appear closely related to any other species of Filago. From a taxonomic point of view, these results clearly support the independence of $F$. lutescens. Moreover, the subspecific rank seems suitable for $F$. lutescens subsp. atlantica.

Clade H corresponded to Holub's $(1975,1976)$ concept of Evax, except that it did not include E. nevadensis and E. crocidion (Fig. 2). Although most of the species of the traditional genus Evax were grouped together, this clade, which also included the type species of the genus E. pygmaea, was merged within the genus Filago. Therefore, Evax should be included in the latter genus as proposed by Wagenitz (1969) and Anderberg (1991). This clade H was constituted by two main groups: one composed by taxa of a wide Mediterranean distribution area (Evax argentea Pomel, E. pygmaea subsp. pygmaea, Evax asterisciflora (Lam.) Pers.), and one composed by taxa with an almost restricted Iberian and Northwest African distribution area (Evax carpetana Lange, E. lusitanica, E. pygmaea subsp. ramosissima). It is worth noting that the different specimens of E. pygmaea and E. argentea do not group together. These results partially reflect the intraspecific variation found in the ITS, ETS and rpl32-trnL intergenic spacer sequences in both species, as commented in the Results section. Smissen \& Breitwieser (2008) have already documented notable intraspecific variation for New Zealand Leucogenes Beauverd (Gnaphalieae), both in nuclear (ITS) and chloroplast ( $p s b A$-trnH intergenic spacer) DNA sequences, which showed the species of this genus to be non-monophyletic in molecular phylogenies. In our case, this sequence polymorphism again suggests hybridization, incomplete lineage sorting, or at least a complex scenario of the relationships among these morphologically well-delimited species. Further studies focused on these two species should be undertaken to understand the structure and causes of the genetic variation detected. Finally, the position of E. pygmaea subsp. ramosissima, not related to subsp. pygmaea, is in agreement with their differences in morphological characters: subsp. pygmaea has a usually unbranched main stem, leaves with the margins slightly recurved downwards to the abaxial face (Fig. $3 \mathrm{~K}$, as Filago pygmaea), and the achenes are longer than $1 \mathrm{~mm}$, glabrous or uniformly covered by small hyaline subspherical trichomes; while subsp. ramosissima has a shorter main stem with long lateral branches procumbent and then ascending, leaves folded upwards to the adaxial face along the medium nerve (Fig. 3L, as Filago gaditana), and the achenes are shorter than $1 \mathrm{~mm}$ long, with sparsely hyaline cylindrical trichomes. These morphological and molecular arguments have led us to consider recognizing E. pygmaea subsp. ramosissima at the species level. Since the name $F$. ramosissima is already in use, we propose the new combination Filago gaditana (Pau) Andrés-Sánchez \& Galbany, comb. nov. (Appendix 2; Table 3).

The last clade, clade I (Figs. S3-S4; Fig. 2), contained several species from Wagenitz's (1969) F. sect. Filago and sect. Evacopsis. Except for $F$. pyramidata and $F$. congesta, the rest of the species have a restricted distribution area, either in Israel and Jordan $(F$. inexpectata) or in the Iberian Peninsula and North Africa (remaining species).

\section{- CONCLUDING REMARKS}

Using a large number of characters from chloroplast and nuclear DNA markers has led to higher resolution in the phylogeny of the tribe Gnaphalieae. However, the phylogenetic relationships of the tribe are still not satisfactorily resolved, and the closest relatives of the Filago group have not been established. Nevertheless, they are shown to belong to the "FLAG clade", which has been newly described for the tribe, and is also constituted by Antennaria, Castroviejoa, Diaperia, Gamochaeta, part of Gnaphalium and Leontopodium.

The generic circumscription of most of the Filago group members and previous infrageneric classifications of Filago do not correspond with the phylogenetic relationships inferred from the sequence data of several markers.

The incongruities found between chloroplast and nuclear DNA sequence analyses show that it is necessary to use both types of DNA in phylogenetic studies of the tribe. The intraspecific variation shown by all the regions sequenced indicates the importance of including several specimens of each species when possible, especially in widely distributed, morphologically variable, or not well-delimited species. It also shows the potential utility of these DNA regions in intraspecific genetic variation studies.

\section{aCKNOWLEDGMENTS}

We are deeply grateful to Prof. G. Wagenitz for helpful discussion on Filago, and Dr. R. Smissen for helpful comments on the manuscript and enthusiastic discussion on Gnaphalieae. We also thank S. Giralt and I. Moreno for translating the diagnoses into Latin. We thank the curators of all herbaria that provided material (BC, BCN, LE, RSA, SALA, W), as well as all the people who provided material from their own collections or assistance during field work, and M. Bongartz for technical assistance. Catherine Stonehouse revised the English of the text. Finally, we also thank Dr. R.J. Bayer, Dr. S. Freire and an anonymous reviewer for helpful comments that have notably improved this work. This work has been partly financed by the Spanish Ministerio de Ciencia e Innovación (CGL2004-04563-C02-01/BOS, CGL200601765/BOS, CGL2007-60781/BOS, CGL2005-05471-C04-03 and CGL2008-02982-C03-02), by the Junta de Castilla y León through the project SA142A08 and by the Catalan government ('Ajuts a grups consolidats' 2009/SGR/00439).

\section{口 LITERATURE CITED}

Akaike, H. 1973. Information theory as an extension of the maximum likelihood principle. Pp. 267-281 in: Petrov, B.N. \& Csaki, F. (eds.), Second International Symposium on Information Theory. Budapest: Akademial Kiado.

Alavi, S.A. 1983. Evax, Filago and Logfia. Pp. 33-61 in: Ali, S.I., Jafri, S.M.H., Siddiqi, M.A. \& Ghafoor, A. (eds.), Flora of Libya, vol. 107. Tripoli: Al Faateh University.

Anderberg, A.A. 1991. Taxonomy and phylogeny of the tribe Gnaphalieae (Asteraceae). Opera Bot. 104: 5-195.

Bayer, R.J., Greber, D.G. \& Bagnall, N.H. 2002. Phylogeny of Australian Gnaphalieae (Asteraceae) based on chloroplast and nuclear 
sequences, the $\operatorname{trn} L$ intron, $\operatorname{trn} L / F$ intergenic spacer, $m a t K$, and ETS. Syst. Bot. 27: 801-814.

Bayer, R.J., Puttock, C.F. \& Kelchner, S.A. 2000. Phylogeny of South African Gnaphalieae (Asteraceae) based on two noncoding chloroplast sequences. Amer. J. Bot. 87: 259-272.

Bentham, G. 1873. Tribus IV. Inuloideae. Pp. 180-318 in: Bentham, G. \& Hooker, J.D. (eds.), Genera plantarum, vol. 2 (1). London: Reeve.

Bergh, N. \& Linder, H.P. 2009. Cape diversification and repeated out-of-southern Africa dispersal in paper daisies (Asteraceae Gnaphalieae). Molec. Phylog. Evol. 51: 5-18.

Boissier, P.E. \& Reuter, G.F. 1875. Micropus. P. 242 in: Boissier, P.E. (ed.), Flora orientalis, vol. 3. Genève, Basel \& Lyon: Georg.

Bolòs, O. \& Vigo, J. 1996. Flora dels Països Catalans, vol. 3. Barcelona: Barcino.

Cassini, H. 1819. Examen analytique du genre Filago de Linné. Bull. Sci. Soc. Philom. Paris, 1819: 141-144.

Cassini, H. 1822. Inulées-Prototypes. Pp. 564-565 in: Cuvier, F. (ed.), Dictionnaire des Sciences Naturelles, ed. 2, vol. 23. Paris: Le Normant.

Castresana, J. 2000. Selection of conserved blocks from multiple alignments for their use in phylogenetic analysis. Molec. Biol. Evol. 17: 540-552.

Cronn, R. \& Wendel, J.F. 2004. Cryptic trysts, genomic mergers, and plant speciation. New Phytol. 161: 133-142.

Cronquist, A. 1950. Notes on the Compositae of the northwestern United States. Leafl. W. Bot. 6: 41-56.

Cullings, K.W. 1992. Design and testing of a plant-specific PCR primer from ecological and evolutionary studies. Molec. Ecol. 1: 233-240.

Doyle, J.J. \& Dickson, E.E. 1987. Preservation of plant samples for DNA restriction endonuclease analysis. Taxon 36: 715-722.

Farris, J.S., Källersjö, M., Kluge, A.G. \& Bult, C. 1995a. Testing significance of incongruence. Cladistics 10: 315-319.

Farris, J.S., Källersjö, M., Kluge, A.G. \& Bult, C. 1995b. Constructing a significance test for incongruence. Syst. Biol. 44: 570-572.

Felsenstein, J. 1985. Confidence limits on phylogenies: An approach using the bootstrap. Evolution 39: 783-791.

Ford, K.A., Ward, J.M., Smissen, R.D., Wagstaff, S.J. \& Breitwieser, I. 2007. Phylogeny and biogeography of Craspedia (Asteraceae: Gnaphalieae) based on ITS, ETS and $p s b A-t r n H$ sequence data. Taxon 56: 783-794.

Galbany-Casals, M., Garcia-Jacas, N., Sáez, L., Benedí, C. \& Susanna, A. 2009. Phylogeny, biogeography, and character evolution in the Mediterranean, Asiatic and Macaronesian Helichrysum (Asteraceae, Gnaphalieae) inferred from nuclear phylogenetic analyses. Int. J. Pl. Sci. 170: 365-380.

Galbany-Casals, M., Garcia-Jacas, N., Susanna, A., Sáez, L. \& Benedí, C. 2004. Phylogenetic relationships in the Mediterranean Helichrysum (Asteraceae, Gnaphalieae) based on nuclear rDNA ITS sequence data. Austral. Syst. Bot. 17: 241-253.

Goloboff, P.A., Farris, J.S. \& Nixon, K. 2003-2005. TNT: Tree Analysis Using New Technology, version 1.1. Program and documentation, available from the authors, and at http://www.zmuc.dk/public/ phylogeny/.

Gu, X., Fu, Y.-X. \& Li, W.-H. 1995. Maximum likelihood estimation of the heterogeneity of substitution rate among nucleotide sites. Molec. Biol. Evol. 12: 546-557.

Hall, T.A. 1999. BioEdit: A user-friendly biological sequence alignment editor and analysis program for Windows 95/98/NT. Nucleic Acids Symp. Ser. 41: 95-98.

Hilliard, O.M. \& Burtt, B.L. 1981. Some generic concepts in Compositae - Gnaphaliinae. Bot. J. Linn. Soc. 82: 181-232.

Hoffmann, O. 1897. Inuleae-Filagininae. Pp. 179-182 in: Engler, A. \& Prantl, K. (eds.), Die natürlichen Pflanzenfamilien, vol. 4(5). Leipzig: Engelmann.

Holub, J. 1975. Bombycilaena, Cymbolaena, Evax, Filago, Ifloga, Logfia and Micropus. Pp. 100-116 in: Davis, P.H. (ed.), Flora of Turkey, vol. 5. Edinburgh: Edinburgh Univ. Press.
Holub, J. 1976. Filago, Ifloga, Logfia, Evax, Bombycilaena, Micropus, Evacidium, Omalotheca and Gnaphalium. Pp. 121-128 in: Tutin, T.G., Heywood, V.H., Burges, N.A., Moore, D.M., Valentine, D.H., Walters, S.M. \& Webb, D.A. (eds.), Flora europaea, vol. 4. Cambridge, London, New York \& Melbourne: Cambridge Univ. Press.

Holub, J. 1998. Reclassifications and new names in vascular plants 1. Preslia 70: 97-122.

Huelsenbeck, P. \& Ronquist, F. 2001. MRBAYES: Bayesian inference of phylogenetic trees. Bioinformatics 17: 754-755.

Humphries, C.J., Murray, B.G., Bocquet, G. \& Vasudevan, K. 1978. Chromosome numbers of phanerogams from Morocco and Algeria. Bot. Not. 131: 391-406.

Jukes, T.H. \& Cantor, C.R. 1969. Evolution of protein molecules. Pp. 21-123 in: Munro, H.N. (ed.), Mammalian protein metabolism. New York: Academic Press.

Keil, D.J. \& Pinkava, D.J. 1976. Chromosome counts and taxonomic notes for Compositae from the United States and Mexico. Amer. J. Bot. 63: 1393-1403.

Leins, P. 1973. Pollensystematischen Studien an Inuleen 2. Filagininae. Bot. Jahrb. Syst. 93: 603-611.

Lessing, C.F. 1832. Synopsis generum compositarum. Berlin: Duncker \& Humblot.

Lidén, M., Fukuhara, T., Rylander, J. \& Oxelman, B. 1997. Phylogeny and classification of Fumariaceae, with emphasis on Dicentra s.l. based on the plastid gene rps16 intron. Pl. Syst. Evol. 206: 411-420.

Linder, C.R., Goertzen, L.R., Heuvel, B.V., Francisco-Ortega, J. \& Jansen, R.K. 2000. The complete external transcribed spacer of 18S-26S rDNA: Amplification and phylogenetic utility at low taxonomic levels in Asteraceae and closely allied families. Molec. Phylog. Evol. 14: 285-303.

Linnaeus, C. 1753. Species plantarum. Stockholm: Laurentius Salvius.

Maddison, D.R. 1991. The discovery and importance of multiple islands of most-parsimonious trees. Syst. Zool. 40: 315-328.

Markos, S. \& Baldwin, B.G. 2001. Higher-level relationships and major lineages of Lessingia (Compositae, Astereae) based on nuclear rDNA internal and external transcribed spacers (ITS and ETS) sequences. Syst. Bot. 26: 168-183.

Mehra, P.N. \& Remanandan, P. 1975. Cytological investigations on Indian Compositae. IV. Tribes Senecioneae, Eupatorieae, Vernonieae, and Inuleae. The Nucleus 18: 6-19.

Merxmüller, H., Leins, P. \& Roessler, H. 1977. Inuleae-systematic review. Pp. 577-602 in: Heywood, V.H., Harborne, J.B. \& Turner, B.L. (eds.), The biology and chemistry of the Compositae, vol. 1. London: Academic Press.

Morefield, J.D. 1992. Three new species of Stylocline (Asteraceae: Inuleae) from California and the Mojave Desert. Madroño 39: 114-130.

Morefield, J.D. 2004. New taxa and names in North American Ancistrocarphus, Diaperia, and Logfia (Asteraceae: Gnaphalieae: Filagininae) and related taxa. Novon 14: 463-475.

Morefield, J.D. 2006. Ancistrocarphus, Diaperia, Filago, Hesperevax, Logfia, Micropus, Psilocarphus, Stylocline. Pp. 443-470 in: Flora of North America Editorial Committee (eds.), Flora of North America north of Mexico, vol. 19. New York \& Oxford: Flora of North America Association.

Nylander, J.A.A. 2004. MrModeltest, version 2. Program distributed by the author. Uppsala: Evolutionary Biology Centre, Uppsala University.

Okuyama, Y., Fujii, N., Wakabayashi, M., Kawakita, A., Ito, M., Watanabe, M., Murakami, N. \& Kato, M. 2005. Nonuniform concerted evolution and chloroplast capture: Heterogeneity of observed introgression patterns in three molecular data partition phylogenies of Asian Mitella (Saxifragaceae). Molec. Biol. Evol. 22: 285-296.

Pignatti, S. 1982. Evax, Filago and Logfia. Pp. 30-35 in: Flora d'Italia, vol. 3. Bologna: Edagricole.

Ronquist, F. \& Huelsenbeck, J.P. 2003. MRBAYES 3: Bayesian phylogenetic inference under mixed models. Bioinformatics 19: 1572-1574. 
Schultz Bipontinus, C.H. 1845. Filagininae. Pp. 309-310 in: Webb, P.B. \& Berthelot, S. (eds.), Histoire naturelle des Iles Canaries, vol. 3 (2.2). Paris: Béthune.

Shaw, J., Lickey, E.B., Schilling, E.E. \& Small, R.L. 2007. Comparison of whole chloroplast genome sequences to choose noncoding regions for phylogenetic studies in angiosperms: The tortoise and the hare III. Amer. J. Bot. 94: 275-288.

Smissen, R.D. \& Breitwieser, I. 2008. Species relationships and genetic variation in the New Zealand endemic Leucogenes (Asteraceae: Gnaphalieae). New Zealand J. Bot. 46: 65-76.

Smissen, R.D., Breitwieser, I. \& Ward, J.M. 2004. Phylogenetic implications of trans-specific chloroplast DNA sequence polymorphism in New Zealand Gnaphalieae (Asteraceae). Pl. Syst. Evol. 249: 37-53.

Smoljaninova, L. 1955. De genere Micropus L. notulae systematicae. Bot. Mater. Gerb. Bot. Inst. Komarova Akad. Nauk S.S.S.R. 17: 447-454.

Smoljaninova, L. 1959. Filagininae. Pp. 281-303 in: Schischkin, B.K. (ed.), Flora of the USSR, vol. 25. Enfield: Science Publishers.

Sun, Y., Skinner, D.Z., Liang, G.H. \& Hulbert, S.H. 1994. Phylogenetic analysis of Sorghum and related taxa using internal transcribed spacers of nuclear ribosomal DNA. Theor. Appl. Genet. 89: 26-32.

Susanna, A., Garcia-Jacas, N., Hidalgo, O., Vilatersana, R. \& Garnatje, T. 2006. The Cardueae (Compositae) revisited: Insights from ITS, trnL-trnF, and matK nuclear and chloroplast DNA analysis. Ann. Missouri Bot. Gard. 93: 150-171.

Swofford, D.L. 2002. PAUP*. Phylogenetic Analysis Using Parsimony (*and Other Methods), version 4.0b10. Sunderland, Massachusetts: Sinauer.

Taberlet, P., Gielly, L., Pautou, G. \& Bouvet, J. 1991. Universal primers for amplification of three non-coding regions of chloroplast DNA. Pl. Molec. Biol. 17: 1105-1109.
Talavera, G. \& Castresana, J. 2007. Improvement of phylogenies after removing divergent and ambiguously aligned blocks from protein sequence alignments. Syst. Biol. 56: 564-577.

Thompson, J.D., Gibson, T.J., Plewniak, F., Jeanmougin, F. \& Higgins, D.G. 1997. The ClustalX windows interface: Flexible strategies for multiple sequence alignment aided by quality analysis tools. Nucleic Acids Res. 25: 4876-4882.

Valdés, B., Rejdali, M., Achhal El Kadmiri, A., Jury, S.L. \& Montserrat, J.M. 2002. Evax, Filago and Logfia. Pp. 640-646 in: Catalogue des plantes vasculaires du nord du Maroc, incluant des clés d'identification, vol. 2. Madrid: CSIC.

Vilatersana, R., Brysting, A.K. \& Brochmann, C. 2007. Molecular evidence for hybrid origins of the invasive polyploids Carthamus creticus and C. turkestanicus (Cardueae, Asteraceae). Molec. Phylog. Evol. 44: 610-621.

Wagenitz, G. 1965. Zur Systematik und Nomenklatur einiger Arten von Filago L. emend. Gaertn. subgen. Filago ("F. germanica" Gruppe). Willdenowia 4: 37-59.

Wagenitz, G. 1969. Abgrenzung und Gliederung der Gattung Filago s.1. (Compositae - Inuleae). Willdenowia 5: 395-444.

Ward, J.M., Bayer, R.J., Breitwieser, I., Smissen, R.D., GalbanyCasals, M. \& Unwin, M. 2009. Gnaphalieae. Pp. 537-585 in: Funk, V.A., Susanna, A., Stuessy, T.F. \& Bayer, R.J. (eds.), Systematics, evolution, and biogeography of the Compositae. Vienna: International Association for Plant Taxonomy.

Watanabe, K. 2010. Index to Chromosome numbers in Asteraceae. http:// www.lib.kobe-u.ac.jp/infolib/meta_pub/G0000003asteraceae_e.

Yang, Z. 1996. Among-site rate variation and its impact on phylogenetic analyses. Trends Ecol. Evol. 11: 367-372.

Appendix 1. Species included in the molecular analyses with voucher information and EMBL accession numbers (ITS; ETS; $r p l 32-$ trnL intergenic spacer; trnL intron and trnL-F intergenic spacer). An asterisk indicates sequences previously published. In brackets, names we consider correct according to the taxonomic treatment derived from our results, but only when they differ from Anderberg's (1991) or Holub's (1975, 1976) criteria (see main text for details).

Anaphalis margaritacea (L.) Benth. \& Hook. f., Canada: J.M. Blanco \& E. Blanco s.n. (BC), FN645827, FN645632, FN649352, FN645762; Antennaria dioica (L.) Gaertn., Spain: Huesca, Ainsa, Santos-Vicente \& al. MS 428 (SALA), FN645833, FN645610, FN649336, FN645790; Athrixia phylicoides DC., Republic of South Africa: Eastern Cape Province, between Mount Fletcher and Rhodes, Romo 14395 \& al. (BC), FN645816, FN645634, FN649330, FN645751; Bombycilaena discolor (Pers.) M. Laínz, (1) Spain: Lleida, between la Floresta and Les Borges Blanques, Galbany \& al. s.n. (BC), FN645844, FN645562, FN649365,-; (2) Spain: Zamora, Cañizal, Martínez-Ortega 1819 \& Andrés-Sánchez (SALA 134225), FN645843, FN645560, FN649364, FN645771; Bombycilaena erecta (L.) Smoljan., Spain: Zamora, Belver de los Montes, Martínez-Ortega 1814 \& Andrés-Sánchez (SALA 134234), FN645842, FN645561, FN649366, FN645770; Castroviejoa montelinasana (Schmid) Galbany, L. Sáez \& Benedí, Italy: Sardinia, Monte Línas, Galbany \& Sáez s.n. (BCN 4644), AY445210*, FN645559, FN649341, FN645792; Cymbolaena griffithii (A. Gray) Wagenitz [Filago griffithii (A. Gray) Andrés-Sánchez \& Galbany, comb. nov.], Armenia: Ararat, Hadis Montains, between Reghtsahem and Vedi, Rico \& al. CN 5695 (SALA 134833), FN645888, FN645608, FN649405, FN645796; Diaperia prolifera (Nutt. ex DC.) Nutt., United States: Baca Co., Comanche National Grassland, Picture Canyon, Weber 18111 (RSA 532974), FN645835, FN645611, -, FN645798; Dolichothrix ericoides (Lam.) Hilliard \& B.L. Burtt, Republic of South Africa: Western Cape Province, southern slopes of Swartberg Pass, Skelmdraai, Romo 14514 \& al. (BC), FN645828, FN645622, FN649332, FN645754; Evacidium discolor (DC.) Maire [Filago discolor (DC.) Andrés-Sánchez \& Galbany, comb. nov.], (1) Morocco: between Zawyat Ahançal and Aït Mhammed, Rico \& al. LM 3534 (SALA 134336), FN645853, FN645564, FN649368, FN645773; (2) Morocco: Xauen, Jbel Lakra, Quintanar 2725 \& al. (SALA), FN645854, FN645565, FN649369, FN645774; Evax anatolica Boiss. \& Heldr. [Filago anatolica (Boiss. \& Heldr.) Chrtek \& Holub], Armenia: Aragatsotn, Monte Aragat, Ghazaravan, road to lake Kari, Rico \& al. LM 2600 (SALA 134834), FN645857, FN645598, FN649400, FN645772; Evax argentea Pomel [Filago argentea (Pomel) Chrtek \& Holub], (1) Morocco: between Guercif and Saka, Andrés-Sánchez 161 \& al. (SALA 134248), FN645860, FN645570, FN649374, -; (2) Morocco: mouth of Moulouya river, Andrés-Sánchez 45 \& al. (SALA 134245), FN645859, FN645569, FN649373, FN645785; Evax asterisciflora (Lam.) Pers. [Filago asterisciflora (Lam.) Sweet], Tunisia: between Nefza and Tabarka, Vilatersana 1316 \& Romo (BC), FN645861, FN645571, FN649375, FN645786; Evax carpetana Lange [Filago carpetana (Lange) Chrtek \& Holub], Spain: Cáceres, Logrosán, Las Chamizas, Santos-Vicente 566 \& al. (SALA 134319), FN645858, FN645568, FN649372, FN645781; Evax crocidion Pomel [Filago crocidion (Pomel) Chrtek \& Holub], Morocco: Taza, Daya Chiker, Andrés Sánchez 216 \& al. (SALA), FN645864, FN645601, FN649403, -; Evax lusitanica Samp. [Filago lusitanica (Samp.) Silva], (1) Spain: Badajoz, Campanario, close to Zújar river, Santos-Vicente 564 \& al. (SALA 134308), FN645866, FN645572, FN649376, FN645769; (2) Spain: Girona, L'Escala, Mas Vilanera hill, Galbany \& al. s.n. (BC), FN645867, FN645573, FN649377, -; Evax nevadensis Boiss. [Filago nevadensis (Boiss.) Wagenitz \& Greuter], (1) Spain: Guadalajara, Campisabalos, AndrésSánchez 114 \& al. (SALA 134265), FN645862, FN645599, FN649401, FN645776; (2) Spain: Granada, Sierra Nevada, way up to Dornajo, Andrés-Sánchez 139 \& al. (SALA 134385), FN645863, FN645600, FN649402, -; Evax pygmaea (L.) Brot. subsp.pygmaea [Filago pygmaea L.], (1) Spain: Badajoz, Monesterio, SantosVicente 563 \& al. (SALA 134315), FN645868, FN645574, FN649379, FN645787; (2) Spain: Minorca island, Sant Esteve, Montes s.n. (BC), FN645870, FN645575, FN649378, -; Evax pygmaea (L.) Brot. subsp. ramosissima (Mariz) R. Fern. \& Nogueira [Filago gaditana (Pau) Andrés-Sánchez \& Galbany, comb. nov.], Portugal: between Porto Cobo and Sines, Rico 7926 (SALA), FN645869, FN645576, FN649380, FN645788; Filago aegaea Wagenitz, Greece: Insel Kefallinía, Hörandl 6539 \& al. (W 1998-03912), FN645865, FN645602, FN649404, FN645809; Filago arenaria (Smoljan.) Chrtek \& Holub, Afghanistan: 20 km S Kandahar, Rechinger 35296 (W 1967-21241), FN645887, FN645597, FN649398, FN645780; Filago arizonica A. Gray, Mexico: Baja California, Valle Las Palmas, Cerro Bola, Boyd 10377 \& al. (RSA 657500), FN645839, FN645615, FN649343, FN645807; Filago californica Nutt., United States: Esmeralda Co., Tule Canyon, Tiehm 14663 (RSA 713363), FN645840, FN645616, FN649344, FN645808; Filago congesta DC., (1) Spain: Lleida, between Omellons and La Floresta, Galbany \& al. s.n. (BC), FN645871, FN645578, FN649381, -; (2) Spain: Granada, Baza, Andrés-Sánchez 52 \& Martínez-Ortega (SALA 134203), FN645848, FN645577, FN649382, FN645768; Filago depressa A. Gray, United States: San Bernardino Co., Mojave desert, Marble Mts., Gross 1927 (RSA 705878), FN645841, FN645617, FN649345, FN645806; Filago desertorum Pomel, (1) Israel: Negev Highlands, Makhtest Ramon, Danin \& al. s. n. (SALA 129597), FN645875, FN645592, FN649392, -; (2) 
Appendix 1. Continued.

Morocco: Taourirt, Narguechoum N slope, Andrés-Sánchez 12 \& al. (SALA 135365), FN645874, FN645591, FN649391, FN645766; Filago duriaei Lange, (1) Spain: Jaén, road JA3303 to Parador Nacional, Andrés-Sánchez 110 \& López-González (SALA 134343), FN645849, FN645586, FN649388, FN645784; (2) Morocco: Taza, Djebel Tazekka, Andrés-Sánchez 210 \& al. (SALA), FN645881, FN645587, FN649389, -; Filago eriocephala Guss., Israel: Philistean Plain, 11km S of Ashkelon, Danin \& al. s.n. (SALA 128912), FN645884, FN645603, FN649407, -; Filago fuscescens Pomel, (1) Spain: Almería, Sorbas, Martínez-Ortega 1794 \& al. (SALA 134373), FN645846, FN645580, FN649394, FN645764; (2) Spain: Almería, Desierto de Tabernas, Martínez-Ortega 1706 \& al. (SALA 134378), FN645845, FN645579, FN649384, -; (3) Spain: Almería, Rambla de Tabernas, Andrés-Sánchez 89 \& al. (SALA 134340), FN645847, FN645585, FN649387, FN645767; Filago hispanica (Degen \& Hervier) Chrtek \& Holub, (1) Spain: Jaén, Pontones, Andrés-Sánchez 123 \& al. (SALA 134351), FN645855, FN645565, FN649370, FN645775; (2) Morocco: Ifrane, Tizi-n-Tretten, Andrés-Sánchez 237 \& al. (SALA), FN645856, FN645567, FN649371, -; Filago inexpectata Wagenitz, Jordan: 15 km SE Ajlun, Schneeweiß s.n. (W 2005-10899), FN645852, FN645584, FN649386, FN645812; Filago lutescens Jord. subsp. lutescens, (1) Spain: Ávila, Bohoyo, Andrés-Sánchez 129 (SALA 134195), FN645876, FN645594, FN649395, FN645777; (2) Spain: Ávila, Navacepeda de Tormes, Martínez-Ortega 1829 (SALA 134165 ), FN645882, FN645596, FN649396, FN645778; (3) Spain: Zamora, Mercado del Puente, Muñoz-Centeno 89 (SALA 134166), FN645883, FN645581, FN649397, FN645779; Filago lutescens Jord. subsp. atlantica Wagenitz, Spain: Huelva, Cortegana, Veredas, Andrés-Sánchez 200 \& Rico (SALA), FN645877, FN645595, FN649399, -; Filago mareotica Delile, Spain: Almería, Cuevas de Almanzora, Guazamara, Santos-Vicente 509 \& al. (SALA 134218), FN645879, FN645593, FN649393, FN645765; Filago micropodioides Lange, (1) Morocco: Taourirt, Narguechoum N slope, Andrés-Sánchez 18 \& al. (SALA 134357), FN645850, FN645582, FN649385, FN645782; (2) Spain: Almería, Laujar de Andarax, Andrés-Sánchez 177 \& Barrios (SALA 134399), FN645851, FN645583, FN645783, --; Filago paradoxa Wagenitz, Turkmenistan: Badkhyz, Keletkaya range, Botchantzev 145 (LE), FN645889, FN645607, FN649363, FN645797; Filago pyramidata L., (1) Spain: Tarragona, Mas de Barberans, Galbany \& Arrabal s.n. (BC), FN645873, FN645590, FN649383, -; (2) Morocco: Souss-Massa-Draa region, prov. Tiznit, Jebel Imzi, Addar river bed, Galbany \& al. s.n. (BC), FN645872, FN645588, FN649390,-; (3) Spain: Balearic islands, Ibiza, Sta. Agnès, Galbany \& al. s.n. (BCN 6124), AY445190*, FN645589,

; Filago ramosissima Lange, Spain: Granada, Sierra Elvira, Andrés-Sánchez 183 \& Barrios (SALA 134399), FN645880, FN645563, FN649367, FN645811; Filago vulgaris Lam., France: Allier, Chassenard, Charpin s.n. (SALA 61802), FN645878, FN645604, FN649406, -; Gamochaeta subfalcata (Cabrera) Cabrera, Spain: Girona, between Mollet de Perelada and St. Climent, Galbany \& al. s.n. (BCN), FN645834, FN645557, FN649338, FN645793; Gnaphalium austroafricanum Hilliard, Republic of South Africa, Kwazulu-Natal Province, between Nottingham Road and Lower Loteni, Romo 14365 \& al. (BC), FN645830, FN645630, FN649353, FN645756; Gnaphalium supinum L., Andorra: Port Creussans, Galbany \& Lluent s.n. (BCN 6121), AY445191*, FN645558, FN649354, FN645789; Gnaphalium uliginosum L., Armenia: Shirak province, Amasia district, NW of village Paghakn, Vitek \& al. s.n. (BCN 39933), FN645823, FN645624, FN649359, FN645757; Helichrysum stoechas (L.) Moench, Spain: Lleida, Galbany s.n. (BCN 6114), AY445225*, FJ211543, FN649351, FN645761; Hesperevax sparsiflora (A. Gray) Greene, United States: San Benito Co., S Inner Coast Ranges, Congdon Peak, Denslow 1128 (RSA 681977), FN645836, FN645618, FN649349, FN645810; Ifloga repens (L.) Hilliard, Republic of South Africa: Northern Cape, Namakwa N. P., Koekemoer 3277 (BC), FN645826, FN645628, FN649357, FN645753; Ifloga spicata (Forssk.) Sch. Bip., Spain: Almería, Cuevas de Almanzora, Santos-Vicente 534 \& al. (SALA 134240), FN645825, FN645627, FN649356, FN645752; Lachnospermum fasciculatum (Thunb.) Baill., Republic of South Africa: Western Cape Province, between Op-die-berg and Citrusdal, Romo 14559 \& al. (BC), FN645829, FN645623, FN649333, FN645755; Lasiopogon muscoides (Desf.) DC., Spain: Almería, Cuevas de Almanzora, Santos-Vicente 499 \& al. (SALA), FN645831, FN645629, FN649334, FN645759; Leontopodium alpinum Cass., Spain: Huesca, Posets, Roquet s.n. (BC), FN645824, FN645625, FN649348, FN645794; Leysera gnaphalodes (L.) L., Republic of South Africa: Western Cape Province, Worcester, NE of Over Hex, Romo 14546 \& al. (BC), FN645815, FN645636, FN649329, FN645750; Logfia arvensis (L.) Holub [Filago arvensis L.], (1) Spain: Jaén, Pontones, Andrés-Sánchez 122 \& al. (SALA 134269), FN645886, FN645606, FN649362, -; (2) Spain: Ávila, Piedrahita, Andrés-Sánchez 85 \& al. (SALA 134283), FN645885, FN645605, FN649361, FN645795; Logfia clementei (Willk.) Holub, Spain: Almería, Rambla de la Galera, Martínez-Ortega 1717 \& al. (SALA 134326), FN645837, FN645612, FN649342, FN645801; Logfia gallica (L.) Coss. \& Germ., Spain: Almería, Sorbas, Martínez-Ortega 1796 \& al. (SALA 134224), FN645838, FN645556, FN649339, FN645799; Logfia heterantha (Raf.) Holub, Italy: Sicily, Palermo, Geraci Siculo, Piano Grande, Güemes \& al. s.n. (SALA 106783), FN645820, FN645614, FN649340, FN645804; Logfia minima (Sm.) Dumort., Spain: Salamanca, San Miguel de Valero, Martínez-Ortega 1805 (SALA 134219), FN645817, FN645613, FN649347, FN645803; Micropus californicus Fischer \& C.A. Meyer, United States: Butte Co., N side of Bardees Bar Road, Ahart 12624 (RSA 712992), FN645821, FN645621, FN649350, FN645800; Micropus supinus L., Spain: Salamanca, Martín de Yeltes, Rico 7883 (SALA), FN645818, FN645609, FN649335, FN645805; Pseudognaphalium luteoalbum (L.) Hilliard \& B.L. Burtt, Portugal: Marinha Grande, Susanna 2435 \& Garcia-Jacas (BCN 6125), AY445231*, FN645633, FN649358, FN645763; Psilocarphus brevissimus Nutt., United States: Riverside Co., Winchester, Riefner 05-237 (RSA 713574), FN645822, FN645620, FN649337, FN645802; Relhania pungens L'Hérit., Republic of South Africa: Western Cape Province, N of Riversdale, top of Garcia's Pass, Koekemoer 3427 (BC), FN645814, FN645635, FN649331, FN645749; Stylocline psilocarphoides M. Peck, United States: Lyon co., Pine Nut Mts., Tiehm 14828 (RSA 712497), FN645819, FN645619, FN649346, FN645791; Syncarpha mucronata (P.J. Bergius) B. Nord., Republic of South Africa: Western Cape Province, Southern slopes of Swartberg Pass, Romo 14511 \& al. (BC 867732), FJ211421* and FJ211479*, FN645626, FN649360, FN645760; Vellereophyton dealbatum (Thunb.) Hilliard \& B.L. Burtt, Republic of South Africa: Western Cape Province, between Ashton and Montagu, Romo 14549 \& al. (BC), FN645832, FN645631, FN649355, FN645758.

Appendix 2. New subgeneric treatment for Filago L. with a subgeneric key and new combinations.

Filago L., Sp. Pl. 2: 927, 1199. 1753.

Filago L. subg. Filago

Filago subg. Oglifa (Cass.) Gren., Fl. Jurass. 2: 430. $1869 \equiv$ Gnaphalium subg. Oglifa Cass. in Bull. Sci. Soc. Philom. Paris, 1819: 143. 1819 [basionym].

Filago subg. Pseudevax (DC.) Andrés-Sánchez \& Galbany, comb. et stat. nov. 三Evax sect. Pseudevax DC., Prodr. 5: 459. 1836 [basionym].

Filago subg. Crocidion Andrés-Sánchez \& Galbany, subg. nov. - Type (designated here): Filago crocidion (Pomel) Chrtek \& Holub.

Crocidion; hoc subgenus ab aliis subgeneribus differt caulibus dichotome ramosis, capitulis in subglobosis glomerulis dispositis; phyllariis absentibus; receptacularibus paleis numero 15-20 variantibus et spiratim dispositis; externis receptacularibus paleis acutis externos femineos flosculos sustinentibus; externis acheniis cum hyalinis cylindricis trichomatibus.

\section{A key for the subgenera of Filago as newly circumscribed:}

1. Phyllaries present; external receptacular paleae deeply enclosing female florets, rarely more or less enclosing them; external achenes smooth, or rarely with sparsely cylindrical trichomes F. subg. Oglifa

1. Phyllaries absent; external receptacular paleae subtending female florets (when these are present); external achenes with hyaline subspherical or cylindrical trichomes

2. Intermediate receptacular paleae obtuse; capitula in pulvinate clusters with $15-20$ receptacular paleae arranged in 5 vertical rows

F. subg. Pseudevax

2. Intermediate receptacular paleae acute or aristate; capitula either in pulvinate clusters with more than 30 receptacular paleae arranged helicoidally or in subglobose clusters

3. Capitula in subglobose clusters with receptacular paleae arranged heli-

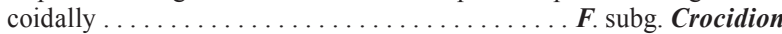

3. Capitula in subglobose clusters with receptacular paleae arranged in 5 vertical rows or in pulvinate clusters . . . . . . . F F subg. Filago

\section{New combinations:}

Filago discolor (DC.) Andrés-Sánchez \& Galbany, comb. nov. $\equiv$ Evax discolor DC., Prodr. 5: 459. 1836 [basionym].

Filago gaditana (Pau) Andrés-Sánchez \& Galbany, comb. et stat. nov. $\equiv$ Evax pygmaea var. gaditana Pau in Mem. Real Soc. Esp. Hist. Nat. 12: 340. 1924 [basionym].

Filago griffithii (A. Gray) Andrés-Sánchez \& Galbany, comb. nov. $\equiv$ Stylocline griffithii A. Gray in Proc. Amer. Acad. Arts 8: 652. 1873 [basionym]. 